
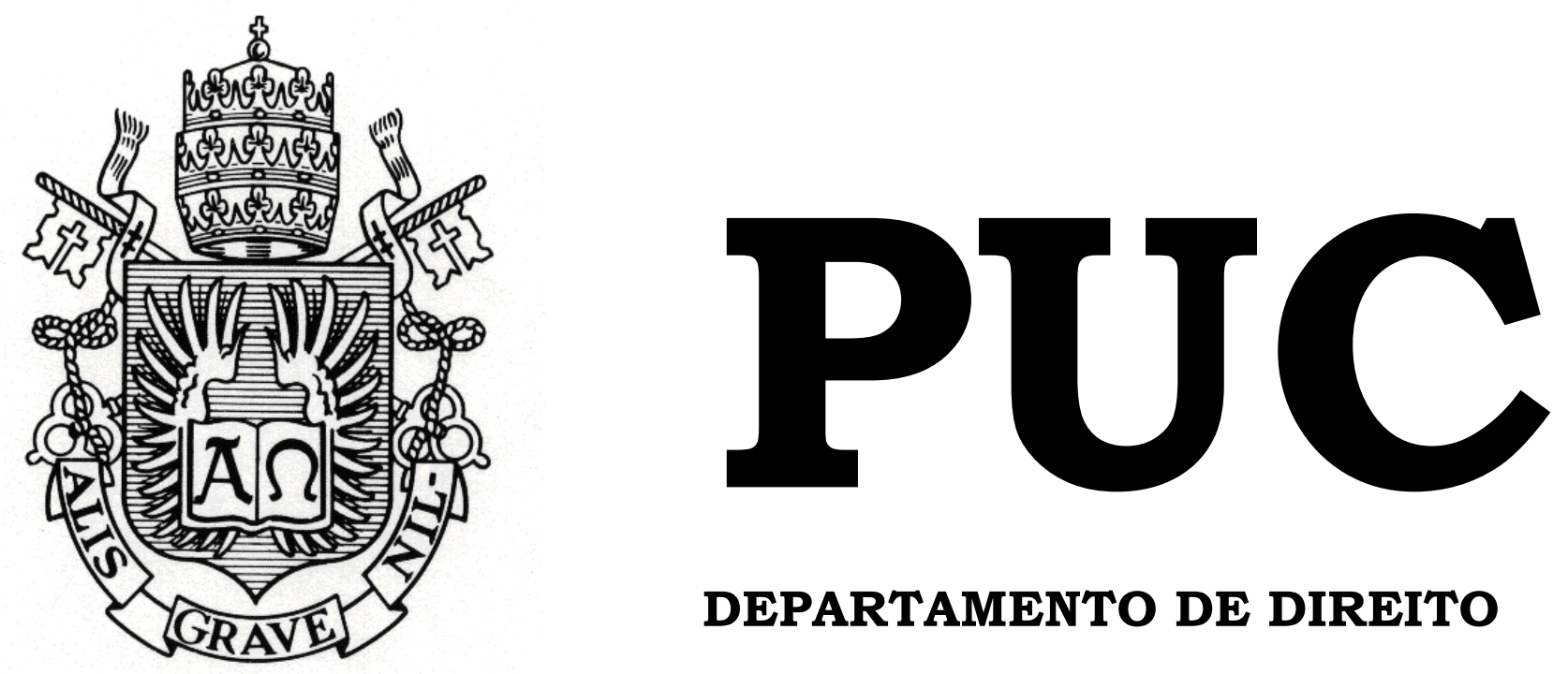

DEPARTAMENTO DE DIREITO

A tributação do Stock Option Plan à luz do direito tributário brasileiro

por

Tamylle Campos Saldanha e Silva

ORIENTADOR: Gustavo Junqueira Carneiro Leão

2015.2

PONTIFÍCIA UNIVERSIDADE CATÓLICA DO RIO DE JANEIRO

RUA MARQUÊS DE SÃO VICENTE, 225 - CEP 22453-900

RIO DE JANEIRO - BRASIL 


\section{A tributação do Stock Option Plan à luz do direito tributário brasileiro}

por

Tamylle Campos Saldanha e Silva

Monografia

apresentada

ao

Departamento de Direito da Pontificia Universidade Católica do Rio de Janeiro (PUC-Rio) como requisito parcial para a obtenção do Título de Bacharel em Direito.

Orientador: Gustavo Junqueira Carneiro Leão 


\section{AGRADECIMENTOS}

Quando acabei o presente estudo, achei que a parte mais difícil já havia passado. Contudo, me deparei com a falta de palavras para iniciar os agradecimentos, já que são tantos e tão sinceros..

Em primeiro lugar, "in memorian” da minha eterna e amada avó materna Clymene Campos Saldanha, que apesar de ter deixado este mundo quando eu iniciava minha trajetória no Direito, foi a maior incentivadora e quem sonhou ao meu lado que isso seria possível. Eu pensei em você a cada dia nessa jornada, e espero que de onde esteja, posso vibrar por esta conquista, pois ela também é sua. Obrigada pelos 19 anos de amor incondicional, proteção, e acima de tudo por nunca ter desistido de mim!.Sempre te amarei.

Aos meus queridos e amados pais Mylene e Zé, que me apoiaram e enfrentaram todo tipo de adversidade para realizar meu sonho. É uma honra poder compartilhar essa vitória com vocês. Afinal, sem vocês, nada disso seria possível. Sempre serão meus maiores exemplos. Obrigada pelo investimento, pelo amor, pela dedicação. Amo vocês.

À minha irmã Tahyssa, por toda paciência e companheirismo nas madrugadas de estudos e momentos de mais puro estresse. Seu jeito meigo e puro muitas vezes me deram força para esquecer a dificuldade e me fizeram seguir em frente. Obrigada por estar sempre ao meu lado.

Ao meu amado namorado Sergio Ricardo por todo amor, carinho, paciência, e acima de tudo, por toda ajuda nessa reta final. Você foi e é essencial na minha jornada, seja na faculdade, seja na vida. Uma vez você disse que juntos somos fortes, e eu acrescento dizendo que: juntos somos invencíveis. Obrigada por tudo! 
Aos meus queridos tios e tias que me incentivaram, acreditaram no meu potencial, e que nunca deixaram eu desistir de mim. Obrigada por toda preocupação e carinho. Serei eternamente grata.

Agradeço ainda às minhas companheiras de tantos momentos, Jaque, Carol, Mari, tudo teria sido mais difícil sem vocês no meu caminho. Obrigada pela amizade e troca de aprendizado nesses 5 anos.

Ainda, agradeço aos meus queridos parceiros de atlética, com certeza poder fazer parte dessa família que ama o esporte tanto quanto eu, completou ainda mais minha caminhada e a encheu de alegrias e satisfação.

Por fim, e não menos importante, agradeço imensamente ao meu orientador e mestre Gustavo Junqueira, pela insistência e por acreditar que eu era capaz de produzir um trabalho de cunho estritamente tributário. Obrigada por aflorar ainda mais minha paixão pelo direito tributário e por contribuir de forma tão significativa para meu aprendizado. 


\section{RESUMO}

SILVA, Tamylle Campos Saldanha. A tributação do Stock Option Plan à luz do direito tributário brasileiro. 78 p. Monografia (Graduação em Direito) - Pontifícia Universidade Católica do Rio de Janeiro: Rio de Janeiro, 2015.

O presente trabalho acadêmico tem como escopo promover uma análise acerca da evolução histórica-contábil dos planos atrelados à ações. Esta monografia estudará a evolução legislativa do tema no Brasil (principalmente analisando a importância do CPC 10 e da nova Lei $\mathrm{n}^{\circ}$ 12.973/14) e sua problemática, acerca da incidência das contribuições previdenciárias e a tributação do Imposto de Renda da Pessoa Física. Neste contexto, serão visitados institutos do direito trabalhista, previdenciário, constitucional, comparado, tributário, bem como noções básicas de direito societário e contabilidade. Por fim, verificar-se-á como a jurisprudência vem se posicionando a respeito do referido tema no âmbito nacional.

\section{Palavras Chave}

Direito Tributário; Planos de Opção de Compra de Ações; Natureza Jurídica; Stock Options Plans; CPC 10; Lei $n^{0}$ 12.973/14; Contribuições Previdenciárias; Base de cálculo; Alíquotas; Imposto de Renda da Pessoa Física. 


\section{SUMÁRIO}

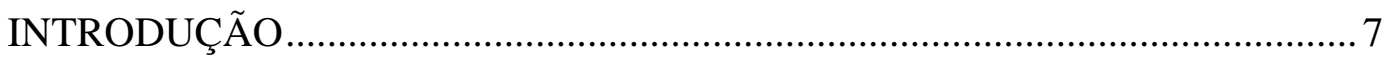

1.1. O Stock Option, sua sistemática operacional e relevância no contexto atual. 8

1.2. Diferimento quanto ao Bônus de subscrição 10

CAPÍTULO 2. A EVOLUÇÃO HISTÓRICO LEGISLATIVA DO TEMA......... 12

2.1. Breve histórico e a herança norte-americana................................................. 12

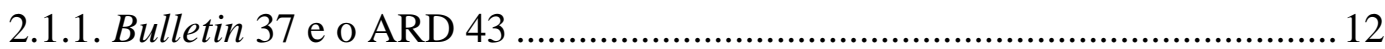

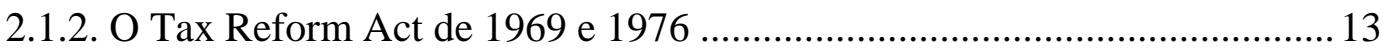

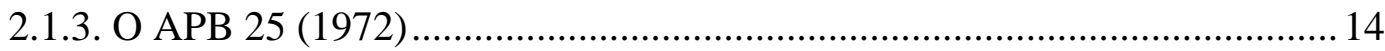

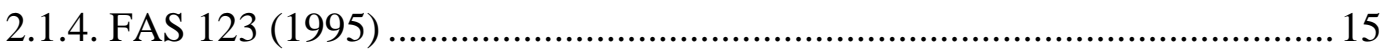

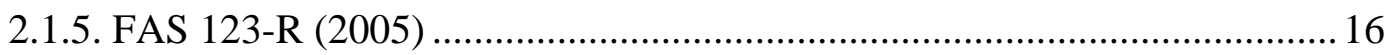

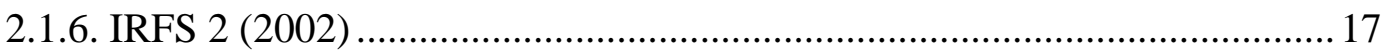

2.2. A normatização no Direito Brasileiro.............................................................. 17

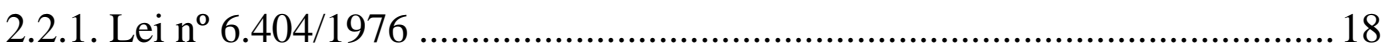

2.2.2. Ofício Circular CVM/SNC/SEP 01/2005_.................................................. 19

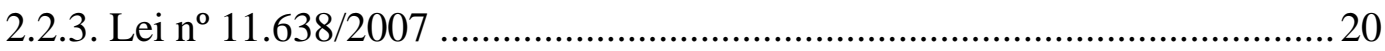

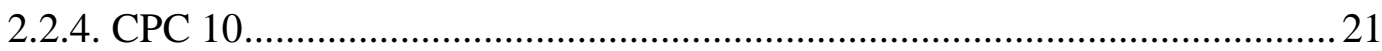

2.2.5. Instrução Normativa CVM no 480/2009..................................................... 22

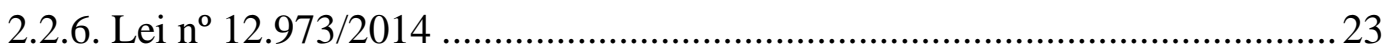

CAPÍTULO 3. PLANOS DE OPÇÃO DE AÇÃO ............................................. 26

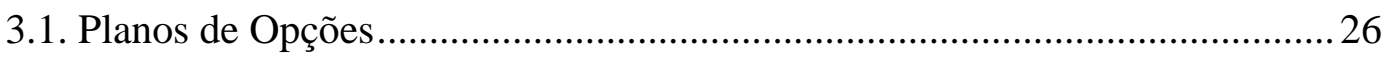

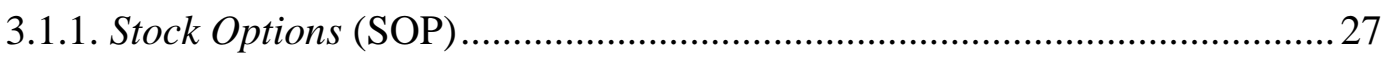

3.1.2. Restricted Stock Units (RSU) ................................................................ 28

3.1.3. Employee Stock Purchase Plans (ESPP)................................................. 29

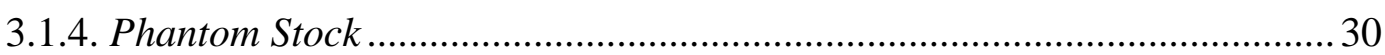

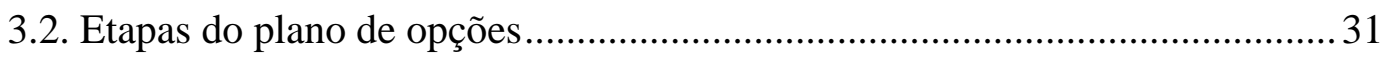

3.2.1. Aprovação do plano de opções................................................................... 31 
3.2.2. Concessão da opção (grant date) 32

3.2.3. Data de início do serviço (service incenption date) .................................. 32

3.2.4. Período de aquisição de direitos .................................................................. 32

3.2.5. Período de carência do maturação (vesting veriod) ..................................... 33

3.2.6. Período de exercício da opção (exercise period) ......................................... 34

3.2.7. Período de inalienabilidade ou trava (lock up period)................................. 34

CAPÍTULO 4. REFLEXOS NAS CONTRIBUIÇÕES PREVIDENCIÁRIAS .. 36

4.1. O conceito de remuneração e seus reflexos previdenciários ........................... 36

4.1.1. Da inexistência de risco .............................................................................. 38

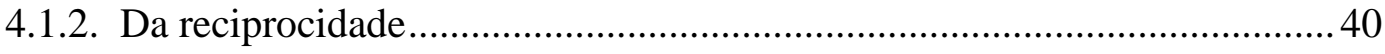

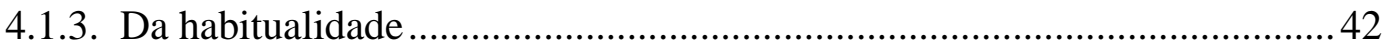

4.2. Da análise específica no Stock Options Plan (SOP) ....................................43

4.3. Da base de cálculo das contribuições previdenciárias e dos valores

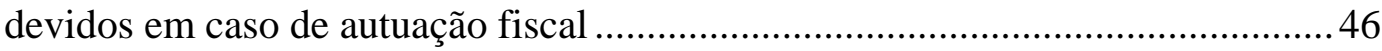

4.4. Jurisprudência do Conselho Administrativo de Recursos Fiscais (CARF) .... 48

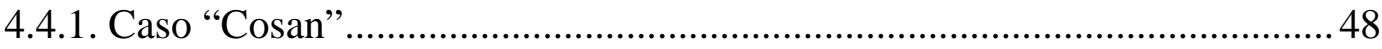

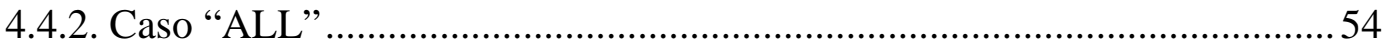

4.5. Jurisprudência na esfera judicial e as tendências da jurisprudência atual ...... 64

CAPÍTULO 5. REFLEXOS NA TRIBUTAÇÃO DO IMPOSTO DE

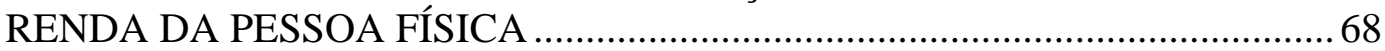

5.1. A tributação da pessoa física do beneficiário ..................................................68

5.2. Fato Gerador do Imposto de Renda - Pessoa Física (IRPF) nos Stock

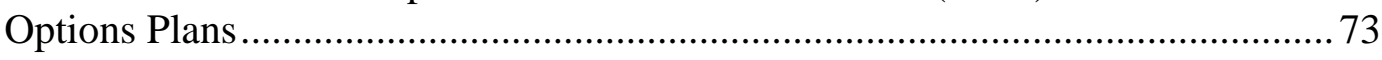

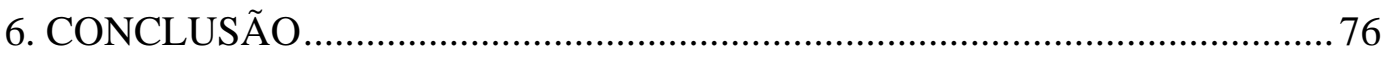

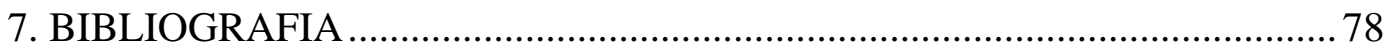




\section{INTRODUÇÃO}

Inicialmente, o presente tema apresenta-se como desafio para os estudiosos direito tributário, em razão da esparsa legislação e jurisprudência fiscal. Conhecida pela sua constante dinâmica, o referido ramo do direito pressupõe não somente o conhecimento técnico específico da área em si, mas também a necessidade de aplicação da interdisciplinaridade, ou seja, o diálogo com demais áreas do Direito.

Em síntese, além da definição do que vem a ser os Planos de Opções de Compras de Ações e sua relação com o atual contexto globalizado, serão resgatados ainda a título introdutório conceitos fundamentais do Direito Tributário e Societário, verdadeiros alicerces da sociedade moderna.

Seguindo essa linha de raciocínio, o segundo capítulo trará a evolução histórica internacional e nacional dos chamados Stock Options Plans, ou como mencionamos acima: Planos de Opções de Compras de Ações. Aproveitar-se-á esta oportunidade para debater toda a controvérsia legislativa contábil sobre o tema.

A seguir, o prosseguimento do estudo se dará à luz dos tipos de Planos de Opções de Compra de Ações mais utilizados atualmente. Além disso, verificaremos a importância de cada etapa dos Stock Options Plans, já que este é o cerne do presente estudo.

Ato contínuo, verificar-se-á a natureza jurídica dos Stock Options Plans, ou seja, verificando os requisitos para ser tratada como mercantil ou caracterizada como remuneração. Neste ponto, o direito trabalhista será um grande amigo para entendermos os conceitos que darão base para a sustentação da incidência ou não das contribuições previdenciárias. A jurisprudência aqui também é fundamental para a análise, tendo em vista que as decisões ainda se dão caso a caso.

Como não poderia deixar de citar, o presente estudo também abordará sobre a tributação da pessoa física do beneficiário dos Planos de Opções de Compra de Ações, partindo do pressuposto que o fato gerador do 
imposto de renda da pessoa física é a disponibilidade econômica da renda, o que acarreta em acréscimo patrimonial.

Por fim, ante todo o exposto, o trabalho será concluído com breves comentários acerca dos resultados obtidos com o presente estudo acadêmico, e conclusões pessoais da autora.

\subsection{O Stock Option, sua sistemática operacional e relevância no contexto atual.}

O mundo ainda vive em um cenário em que cabe dizer que a Globalização ainda tem muita influência sobre nossas vidas. Isso também ocorre no mundo das empresas.

Cada vez mais, busca-se formas não somente para atrair o empregado, mas também para retê-lo na empresa, evitando assim, que haja um excessiva rotatividade, ou seja, o que chamamos de turnover.

Os stock options plans nascem justamente nesse necessário em que os empregadores almejam maior estabilidade e durabilidade do contrato de trabalho com seu empregado.

Mas o que vem a ser efetivamente os stock options plans? Em uma tradução mais fidedigna para o português, dizemos que é a concessão de um plano de opção para a compra de ações. Os referidos planos concedem aos empregados, desde que cumpridas as metas e decorrido o prazo de carência, o direito de adquirir ações da companhia ou de sua controladora a um preço pré-fixado.

O Barron's Dictionary of Legal Terms define Stock Option como “a outorga a um indivíduo do direito de comprar, em uma data futura, ações de uma sociedade por um preço especificado ao tempo que a opção lhe é conferida, e não ao tempo em que as ações são adquiridas”.

Como veremos adiante, esse instituto surgiu no Brasil nos anos 90, mas ainda com uma aparência um tanto precária, sem muita forma. Esse é um dos motivos que faz o tema ainda carecer de efetiva regulamentação no 
âmbito trabalhista, societário, e consequentemente, no tributário, refletindo diretamente nos conflitos gerados pelas autuações da Receita Federal do Brasil.

Em regra, as stock options são utilizadas pelas Sociedades por Ações, por isso faz-se necessário resgatarmos um pouco o tema, para entendermos seu funcionamento, antes mesmo de começarmos a análise do instituto em si.

Segundo Fábio Ulhoa Coelho, "as sociedades anônimas correspondem à forma jurídico-societária mais apropriada aos grandes empreendimentos econômicos” ${ }^{1}$. Assim, as sociedades anônimas ou companhias, além de seu caráter empresarial, têm a questão referente a responsabilização dos sócios, também conhecidos como acionistas, que será limitada ao preço das ações que compõe seu patrimônio.

As ações refletem a divisão do capital social da empresa, funcionando também como uma espécie de valor mobiliário. A pessoa que adquirir ações de uma empresa torna-se sócio dela, recebendo dividendo por deter esta titularidade.

Porém, há outros meios de se negociar e vender ações, porém sempre observando o tipo de sociedade anônima em análise. As companhias de capital fechado dependem de previsão estatutária dos requisitos para compra e venda ou para a própria negociação de ações. Por outro lado, quando falamos em sociedade de capital aberto, as ações são negociadas aberta e publicamente no mercado de valore mobiliários.

No que diz respeito aos valores das ações, precisamos observar sob qual prisma queremos analisar, tendo em vista que tal análise poderá ser feita sob a ótica do valor nominal ou do valor patrimonial da ação.

O valor nominal consiste no valor da ação no mercado no momento de sua emissão. Já o valor patrimonial demonstra a divisão entre o patrimônio líquido da empresa e as suas ações. Mas, no final o que de fato é

\footnotetext{
${ }^{1}$ COELHO, Fábio Ulhoa. Curso de Direito Comercial V.2: Direito de Empresa.17.ed. São Paulo: Saraiva, 2013.
} 
levado em consideração é o valor que demonstra o que efetivamente foi auferido com a venda da participação acionária. Chamamos isso de valor de mercado ou de negociação.

Na comercialização da ações, o retorno financeiro se dá justamente porque o valor de negociação, acima mencionado, é variável, não precisando assim, coincidir com o preço de emissão das ações (preço efetivamente pago pelos acionistas, diretamente as companhias, no momento de sua emissão).

Após uma breve introdução sobre o que vem a ser o instituto dos stock options plans, bem como seu ganho de relevância no mundo globalizado, passamos a agora a entender de fato como ele se opera, estabelecendo em primeiro lugar uma diferenciação do que chamamos de bônus de subscrição.

\subsection{Diferimento quanto ao Bônus de subscrição}

No direito brasileiro, as stock options compreendem duas vertentes distintas, e são elas: a opção de compra em si e os bônus de subscrição. De acordo com os ensinamentos de Modesto Carvalhosa ${ }^{2}$ :

"As stock options foram trazidas para o nosso direito por meio de dois diferentes institutos: a opção de compra, especialmente criada para atender aos interesses dos administradores, empregados e contratantes, com respeito às emissões de capital da companhia, e os bônus de subscrição, que têm como objetivo viabilizar a obtenção de capitais financeiros para a companhia, racionalmente, em termos de mercado e de adesão de novos investidores ou de incentivo aos acionistas ou debenturistas.”

Por se tratar de diferentes institutos, devemos traçar um paralelo entre elas, para que em momento futuro não se faça confusão em relação à tributação das stock options.

O bônus de subscrição tem previsão legal nos artigos 75 a 79 da Lei das S.A., e para Fábio Ulhoa Coelho, “é o valor mobiliário que atribui ao

\footnotetext{
${ }^{2}$ CARVALHOSA, Modesto. Comentários à lei de sociedades anônimas. V.2. 4.ed. rev.e atual. São Paulo: Saraiva, 2008.
} 
seu titular o direito de preferência para subscrever novas ações da companhia emissora, quando de futuro aumento de capital social”3.

Já as stock options referem-se à possibilidade do empregado adquirir ações da companhia, em um determinado período e por preço ajustado previamente, além de haver a necessidade de se atingir metas também préacordadas.

Os dois pontos critérios essenciais que diferenciam as stock options do bônus de subscrição são: a possibilidade de transferência das ações e para quem se está transferindo (destinatário).

Nesse cenário, as stock options configuram títulos personalíssimos e não negociáveis, cujos destinatários são aqueles que participam da vida da companhia (empregados, administradores e prestadores de serviços).

Já os bônus de subscrição, por outro lado, podem ser definidos como títulos largamente negociáveis, estando à deriva no mercado de capitais, podendo a qualquer momento ser concedidos a novos investidores, acionistas ou debenturistas. ${ }^{4}$

\footnotetext{
${ }^{3}$ COELHO, Fábio Ulhoa. Curso de Direito Comercial V.2: Direito de Empresa.17.ed. São Paulo: Saraiva, 2013.

${ }^{4}$ CARVALHOSA, Modesto. Comentários à lei de sociedades anônimas. V.2. 4.ed. rev.e atual. São Paulo: Saraiva, 2008. p.15.
} 


\section{CAPÍTULO 2. A EVOLUÇÃO HISTÓRICO LEGISLATIVA DO TEMA}

\subsection{Breve histórico e a herança norte-americana}

A titulo de recordação, muito antes do surgimento dos planos de remuneração com base em ações, algumas empresas americanas já almejavam o mesmo objetivo buscado atualmente pelas stock options, qual seja, a necessidade de alinhamento dos interesses de executivos e acionistas, bem como reter funcionários talentosos.

Neste sentido, progressivamente os modelos de incentivo de longo prazo foram se tornando ferramentas cada vez mais comuns, ao passo que nos anos 80, os Estados Unidos presenciaram um aumento substancial na quantidade de stock options oferecidas a funcionários.

Isto devido ao tratamento contábil favorecido pelos princípios vigentes a época, bem como em razão da ausência de tributação dos ganhos na data do oferecimento, caso o preço de exercício da opção fosse igual ao preço da ação.

Com efeito, embora exista uma relação muito antes do surgimento dos planos de remuneração com base em ações - necessidade de alinhamento de interesses de executivos e acionistas.

Passaremos agora a analisar os documentos que tiverem considerável importância no cenário internacional, e que serviram como o pontapé inicial para delimitar a matéria e tentar normatizá-la.

\subsubsection{Bulletin 37 e o ARD 43}

O "Bulletin 37: Accounting for Compensation in the Form of Stock Options", foi um dos documentos pioneiros sobre o tema, abordado pelo Comitê de Procedimentos Contábeis Americano (CAP - Comnittee on 
Accounting Procedure), vigorando de 1948 a 1953, quando a tributação referente a renda advinda das opções de ações dos empregados, sofreu alteração.

Tal alteração na legislação tributária acarretou na revisão do Bulletin 37, e na sua ampliação, surgindo assim o "Accounting Research Bulletin" ${ }^{0}$ 43, também chamado de “ARB 43”.

O Capítulo 13B: "Compensation Involved in Stock Option and Stock Purchase Plans" nos dá um breve noção de que o entendimento adotado à epóca era de que as opções de compra de ações estariam incluídas no custo dos serviços prestados/recebidos.

Também é possível verificar que para que o empregado pudesse exercer o direito da opção deveria antes cumprir pré-requisitos como por exemplo permanecer na empresa por determinado período de tempo, exercer as ações exclusivamente com o objetivo de realizar investimentos, não podendo assim, negociá-las futuramente (revenda).

Diante disso, podemos vislumbrar a importância deste documento, tendo em vista que representa a origem, do que temos atualmente no tocante à exigência de determinações, metas e condições pré estabelecidas para que o empregado possa efetivamente exercer seu direito de opção de ações.

\subsubsection{O Tax Reform Act de 1969 e 1976}

Nos anos 70, os Estados Unidos passaram um período de grande utilização das stock options. Isto porque, eram oferecidas vantagens fiscais às empresas e aos seus funcionários.

Na época, a forma mais utilizada como incentivo, devido a maior diversidade de benefícios fiscais que oferecia, eram as stock options qualificadas (Qualified Stock Options - QSO). Este gênero englobava duas espécies quais sejam: stock options de incentivo e stock options para empregados. 
Ocorre que, com o Tax Reform Act em 1969, as então vantagens fiscais concedidas pelo governo americano, foram reduzidas tocante às stock options qualificadas no que diz respeito aos empregados. Por outro lado, aumentou os benefícios para as empresas, equilibrando eventuais prejuízos causados ao empregado.

Em 1976, veio o novo Tax Reform Act, que proibiu a utilização de novos planos de stock options qualificadas o que ocasiou uma queda na sua utilização e, consequentemente, aumentou o uso de stock options não qualificadas (Non Qualified Stock Option - NQSO), ainda que representassem menor vantagem do ponto de vista fiscal.

\subsubsection{O APB 25 (1972)}

O APB 25 é um outro documento que deve ser mencionado devido a sua importância para o tema. Apesar de não abordar a questão fiscal, com o seu advento, o ARB 43 foi por ele incorporado, tornando-se seu Anexo B.

Este documento, também conhecido como Accounting for Stock Issued to Employees, trouxe perspectivas acerca do evento, que poderia ser baseado tanto na data de concessão, quanto na data de exercício. Também era possível observar desde já as observância referente as dificuldades enfrentadas na utilização destes métodos. Por fim, já se falava na utilização do valor intrínseco, que representava justamente a diferença entre o valor de mercado e o preço de exercício da ação.

Com a publicação da fórmula de Black-Scholes e a abertura da Bolsa de Opções de Ações de Chicago, apenas um ano após a publicação do APB 25, sua credibilidade caiu, e sua utilização caiu em desuso.

Aqui podemos perceber que houve uma alta no mercado de opções, o que consequentemente gerou um aumento da figura das stock options oferecidas a empregados.

A grande crítica que se fazia ao APB 25 quando comparado à fórmula de Black-Scholes era de que, o primeiro considerava o valor 
intrínseco como válido (e não o valor justo), o que causaria distorções na sua apuração.

Por outro lado, a fórmula de Black-Scholes considerava uma gama de fatores para estabelecimento do preço da opção, ajustando-o assim às suas próprias peculiariaridades, como por exemplo, prazo de vencimento, taxa de juros, etc).

Muitos órgãos normalizadores também se queixavam sobre real utilidade e até mesmo eficiência. Isto porque, trazia diferentes especificações quanto as datas para cotação do preço da ação, em função das metas, condições e requisitos estabelecidos no acordo para com a companhia.

\subsubsection{FAS 123 (1995)}

A fim de uma revisão ampla sobre o assunto, A publicação do FAS 123 em 1995 veio como resultado de quase 10 anos de estudos sobre o tema. Tal documento tinha caráter recomendatório no tocante à prestação de informações quanto a valorização das opções oferecidas.

Vale destacar que aqui, a valorização supracitada levava em consideração o valor justo de mercado, utilizando o modelo adotado pela fórmula Black-Scholes de opções. O FAS 123 permitia a utilização do APB 25 pelas empresas, mas para que isso fosse de fato aceito, o valor deveria constar nas notas explicativas do balanço.

Como o FAS 123 deixou a critério das empresas decidir qual caminho seguir, as empresas em sua grande maioria optaram pela utilização do APB 25, ou seja, consideravam em seu cálculo apenas o valor intrínseco, descartando as peculiaridades que dariam condições de se apurar o valor justo.

O caráter recomendatório para que se informasse a valorização das opções tinha como fundamento a essencialidade das ações executivas (aquelas oferecidas aos empregados) no renascimento da economia norte- 
americana. Sendo assim, mudanças nas regras contábeis soariam como possível ameaça ao que estava dando certo.

Porém, por se tratar apenas de recomendação, não configurando um desobrigação por parte das empresas, elas decidiram por ignorar, lançando como sempre fizeram, apenas o valor intrínseco à data da concessão.

Com o passar dos anos, os investidores começaram a perceber que utilizar o valor intrínseco de fato gerava diversas distorções no fluxo de caixa da empresa. Isso se dava em razão da não contabilização do valor efetivo das ações oferecidas aos seus empregados, pois se oferecessem as mesmas ações no mercado, obteriam um valor maior por elas.

\subsubsection{FAS 123-R (2005)}

Nada mais é do que uma nova versão do FAS 123, elaborada na tentativa de unificar as normas emanadas pelo FASB e IASB.

Segue abaixo tabela comparativa com as principais alterações:

\begin{tabular}{|l|c|c|}
\hline \multicolumn{1}{|c|}{ FAS 123 } & FAS 123 - R \\
\hline $\begin{array}{l}\text { cálculo das } \\
\text { opções }\end{array}$ & $\begin{array}{c}\text { cálculo com base no valor } \\
\text { intrínseco das opções }\end{array}$ & $\begin{array}{c}\text { cálculo com base no valor } \\
\text { justo das opções }\end{array}$ \\
\hline $\begin{array}{l}\text { Operações } \\
\text { com reflexo } \\
\text { no passivo }\end{array}$ & $\begin{array}{c}\text { utilização do valor intrínseco } \\
\text { até a liquidação da } \\
\text { operação }\end{array}$ & $\begin{array}{c}\text { obrigava ao cálculo do } \\
\text { valor justo }\end{array}$ \\
\hline $\begin{array}{l}\text { Operações } \\
\text { com reflexo } \\
\text { no PL }\end{array}$ & $\begin{array}{c}\text { recomendava o cálculo do } \\
\text { valor justo pela fórmula de } \\
\text { Black-Scholes }\end{array}$ & $\begin{array}{c}\text { justo a partir de modelos } \\
\text { que se adequassem às } \\
\text { características das opções }\end{array}$ \\
\hline
\end{tabular}

Dessa forma, é possível verificar que a adoção do valor justo tornouse obrigatória, bem como seu cálculo passou a ser realizado não mais com base na fórmula oferecida pelo Black-Scholes, e sim de acordo com os modelos que melhor se adequassem ao modelo de ações utilizado, o que permitiu maior mobilidade contábil por parte das empresas. 


\subsubsection{IRFS 2 (2002)}

A matéria contábil ganho espaço no cenário mundial, o muitos organismos decidiram trate sobre o tema, agora não mais só nos Estados Unidos. Na Europa, o assunto ganhou tanta visibilidade, que apesar dos países ainda não terem legislações específicas, o atual International Accounting Standards Board, colocou o assunto em pauta em 2001.

Muitos países contribuíram por meio de estudos sobre o assunto, demais documentos foram publicados, até que em conjunto com o FASB, foi então publicado o IFRS.

Deste modo, o FAS 123 -R e o IFRS 2 passaram a ser os documentos de observância obrigatória por parte das empresas, em que essas deveriam contabilizar os planos de stock options em seu balancete como despesas.

Conforme já vimos, o FAS 123-R obrigava o cálculo do valor justo a partir de modelos que se adequassem às características das opções, ou seja, o valor da despesa a ser contabilizada deveria ser baseada no ganho provável.

A partir do momento em que as stock options foram contabilmente consideradas como despesas, a preocupação que surgiu foi em relação ao valor a ser considerado efetivamente como despesa, e como se acompanharia a oscilação desse valor até o exercício o não da opção pelo empregado.

\subsection{A normatização no Direito Brasileiro}

A normalização no direito brasileiro teve início na década de 70, e apesar de já podermos identificar grande avanço, a legislação ainda é falha. Porém é inegável, que se atualmente foi possível conquistarmos a aprovação do Pronunciamento Técnico CPC10 (Pagamento Baseado em Ações) pela Deliberação CVM nº 562/2008, foi devido ao árduo trabalho da área contábil. 
Sendo assim, passaremos então a analisar aos poucos como se deu essa normalização, verificando também seus avanços, porém, sempre lembrando que a CVM não é o órgão responsável por ditar as normas a serem utilizadas pelas fiscalização em relação ao seu ato de tributar.

Portanto, apesar de sua importância histórica como veremos a seguir, para fins estritamente tributários não há significativa representação, que começou a ser mais efetiva a partir de legislações mais especificas que abordaram o tema envolvendo de fato seus reflexos na tributação.

\subsubsection{Lei $n^{\circ} 6.404 / 1976$}

A primeira manifestação acerca do tema no Brasil, foi através da Lei $n^{0}$ 6.404/76, uma legislação societária que já mostrava o interesse, e de certa forma a preocupação dos legisladores em positivar o tema no direito brasileiro.

Sendo assim, a referida lei trata da questão nos artigos 166, 168 e 176, in verbis:

“Art. 166. O capital social pode ser aumentado:

(...)

III - por conversão, em ações, de debêntures ou parte beneficiárias e pelo exercício de direitos conferidos por bônus de subscrição, ou de opção de compra de ações; (Vide Lei n ${ }^{\circ} 12.838$, de 2013)"

"Art. 168. O estatuto pode conter autorização para aumento do capital social independentemente de reforma estatutária.

(...)

$\S 3^{\circ} \mathrm{O}$ estatuto pode prever que a companhia, dentro do limite de capital autorizado, e de acordo com plano aprovado pela assembléia-geral, outorgue opção de compra de ações a seus administradores ou empregados, ou a pessoas naturais que prestem serviços à companhia ou a sociedade sob seu controle.”

“Art. 176. Ao fim de cada exercício social, a diretoria fará elaborar, com base na escrituração mercantil da companhia, as seguintes demonstrações financeiras, que deverão exprimir com clareza a situação do patrimônio da companhia e as mutações ocorridas no exercício:

(...)

$\S 4^{\circ}$ As demonstrações serão complementadas por notas explicativas e outros quadros analíticos ou demonstrações contábeis necessários para esclarecimento da situação patrimonial e dos resultados do exercício.

(...)

§ 50 As notas explicativas devem: (Redação dada pela Lei ${ }^{0} 11.941$, de 2009)

(...) 
g) as opções de compra de ações outorgadas e exercidas no exercício; (Incluído pela Lei ${ }^{0} 11.941$, de 2009)”

Diante desta legislação, temos que além da observância por parte da CVM com relação aos planos de opção de compra de ações, no presente caso, relacionado às companhias abertas, há requisitos mínimos a serem seguidos.

Em síntese, tanto a outorga de opção de compra de ações, quanto a previsão no estatuto social da companhia do capital autorizado (e seus limites) para tal, devem fazer parte de um plano obrigatoriamente aprovado em assembléia geral, sendo destinados aos "administradores ou empregados, ou a pessoas naturais que prestem serviços à companhia ou à sociedade sob seu controle".

Aqui, vale ressaltar que em relação à Deliberação CVM nº 371/2000, esta excluiu do cerne de sua discussão a questão referente a contabilização dos benefícios atribuídos aos empregados, excluindo assim as remunerações baseadas em ações. Portanto, apenas se ateve em promover apenas a natureza e as condições dos planos de remuneração em ações, a esfera contábil e o valor e quantidade pelas quais as ações foram efetivamente emitidas.

\subsubsection{Ofício Circular CVM/SNC/SEP 01/2005}

Apesar de não ter caráter obrigatório, o Ofício Circular CVM/SNC/SEP 01/2005 permitia que as empresas reconhecessem a remuneração baseada em ações como despesas, porém sem trazer qualquer definição quanto ao modelo a ser utilizado para sua precificação, ficando a escolha a cargo de cada companhia.

Por outro lado, o documento em questão trazia a obrigatoriedade de que os detalhes referentes ao Plano de Ações fossem mencionados em notas explicativas. Ocorre que, não obstante a imposição requisitada pelo Ofício, as empresas na maioria das vezes divulgavam informações insuficientes, 
não apresentando todos os quesitos solicitados. $O$ Ofício seguinte (01/2006), não trouxe significativas alterações.

Como já mencionado, é forçoso que tenhamos em mente que qualquer Ofício ou Deliberação realizada pela CVM não possui condão para interferir na esfera tributária, acarretando assim em certa insignificância do feito para as autoridades administrativas, que continuarão seguindo demais regras para efetuar a tributação pertinente.

\subsubsection{Lei $n^{\circ} 11.638 / 2007$}

As normas contábeis transmitidas pela CVM começaram a ser elaboradas de acordo com os padrões internacionais de contabilidade. Isso possibilitou a elaboração da Lei $\mathrm{n}^{0} 11.638 / 07$, que significou um ajuste ao mundo atual dos negócios, na tentativa de propiciar maior transparência às atividades empresariais brasileiras.

Sendo assim, sua proposta objetivava não somente a alteração de artigos da Lei $\mathrm{n}^{0}$ 6.404/76, como também gerar um ambiente mais confortável para as empresas, através de uma legislação com padrões internacionais e mais aprofundada em matéria contábil e societária.

É também nesse cenário que o CPC (Comitê de Pronunciamentos Contábeis) , criado em 2005, ganha força, passando a ter grande importância, pois se tornou responsável pela elaboração e transmissão dos pronunciamento baseados nas normas do IASB, que então passavam pela aprovação tanto da CVM quanto de demais órgãos reguladores, como por exemplo, o CFC.

Conclui-se então, que a Lei $n^{0} 11.638 / 07$ permitiu um processe mais célere de convergência entre as normas brasileiras e as internacionais, passando assim a adotar normas como o CPC 10, que funciona como norte em matéria contábil no que se refere as stock options no Brasil. 


\subsubsection{CPC 10}

O Pronunciamento Técnico CPC 10 (R1), publicado em 2008, é o documento de maior importância para nossa análise, tendo em vista que foi a norma pioneira especifica sobre o assunto no Brasil. Teve como delimitação temática o pagamento baseado em ações, em total consonância com os ditames referentes à Correlacão às Normas Internacionais de Contabilidade - IFRS 2 (IASB - BV 2010).

Sendo assim, seu objetivo consistia em "estabelecer procedimentos para reconhecimento e divulgacão, nas demonstracõos contábeis, das transaç̃oses com pagamento baseado em aç̃es realizadas pela entidade. Especificamente, exige-se que os efeitos das transacões com pagamento baseado em aç̃es estejam refletidos no resultado e no balanço patrimonial da entidade, incluindo despesas associadas com transacõos por meio das quais opcões de aç̃es são outorgadas a empregados”.

O CPC 10 veio a ser implementado com caráter obrigatório, o que fez com que sua aplicabilidade desse mais aparato às definições estabelecidas pela norma, passando esta a ser de fato mais utilizada pelas empresas.

Dentre as várias determinações positivadas por meio do CPC 10, vale ressaltar que a referida norma definiu que a contabilização da despesa deveria ser feita com base no valor justo da opção, porém não definiu nenhum moei específico de precificação, ficando assim, a cargo da empresa escolher o que melhor se ajustasse ao perfil da opção oferecida. Além disso, a contabilização também deveria ser feita de acordo com o regime de competência, tendo início a partir da data da outorga. Seguem os itens 7 e 8 do CPC 10, que dizem respeito ao reconhecimento:

\footnotetext{
"Reconhecimento

7. A entidade deve reconhecer os produtos ou os servicos recebidos ou adquiridos em transacão com pagamento baseado em acões quando ela obtiver os produtos ou à medida que receber os serviços. Em contrapartida, a entidade deve reconhecer o correspondente aumento do patrimonio líquido se os produtos ou serviços forem recebidos em transacão com pagamento baseado em acões
} 
liquidada em instrumentos patrimoniais, ou deve reconhecer um passivo, se os produtos ou serviços forem adquiridos em transacão com pagamento baseado em ações liquidada em caixa (ou com outros ativos).

8. Os produtos ou serviços recebidos ou adquiridos em transacão com pagamento baseado em ações que não se qualifiquem para fins de reconhecimento como ativos, devem ser reconhecidos como despesa do período.”

Já com relação ao valor de aquisição de ações, o CPC é claro em estabelecer em seu item B.2, que "o valor justo das ações deve ser mensurado pelo preço de mercado das acões da entidade (ou preço de mercado estimado, se as aç̃̃es não forem negociadas publicamente), ajustado pelos termos e condicões sob os quais as aç̃os foram outorgadas (exceto pelas condicões de aquisicão de direito que devem ser excluídas da mensuracão do valor justo, conforme disposto nos itens 19 a 21)”.

Ademais, o CPC 10 além de estabelecer uma temática referente ao estabelecimento do valor justo e sua mensuração, também trouxe à tona discussões sobre as formas de liquidação da operação, as condições de aquisição de ações e suas implicações no que diz respeito à outorga de opções. Isto possibilitou que os profissionais da área contábil pudessem ter uma norma norteadora e eficaz quanto às stock options.

\subsubsection{Instrução Normativa CVM nº $480 / 2009$}

No ano de 2009, a CVM publicou nova Instrução Normativa $n^{\circ} 480$, que tinha como objetivo central a obrigatoriedade das empresas abertas a partir de 2011, ao preenchimento e publicação do "Formulário de Referência”.

Este formulário trazia itens concernentes à utilização de stock options, em que deveriam ser apresentadas informações como: termos e condições gerais do plano, condição de aquisição de ações, os critérios para precipitação de aquisição ou exercício, liquidação de ações, e demais informações imprescindíveis quanto ao modelo utilizado, premissas do modelo, volatilidade esperada e peculiaridades da mensurarão do valor justo. 
Observa-se então, que na verdade, a CVM por meio desta Instrução Normativa, consolidou as previsões do CPC 10, colocando as empresas agora no patamar prático de aplicação das normas ali previstas.

Atualmente a Instrução Normativa $n^{0} 480$ sofreu diversas alterações, porém, a mais significativa para nós no âmbito das stock options é a Instrução Normativa CVM n ${ }^{0} 552$ de outubro de 2014, que trouxe alterações especificamente relativas à nova redação dada ao Anexo 24 da Instrução 480, de 2009 (Formulário de Referência).

Contudo, cumpre salientar que as referidas alterações somente entram em vigor a partir de $1^{\circ}$ de janeiro de 2016. Por esse motivo, não foi possível ter acesso ainda a essas alterações, tendo em vista que não estão refletidas no texto consolidado disponível para consulta.

\subsubsection{Lei $n^{\circ} 12.973 / 2014$}

Conforme já visto, o objetivo dos estudioso da área contábil era permitir a convergência da contabilidade brasileira aos padrões internacionais.

O CPC 10 foi um grande instrumento que impulsionou essa convergência, porém, foi através da Lei ${ }^{\circ}$ 12.973/14 que seus reflexos começaram a surtir efeito no mundo jurídico-tributário.

Ocorre que, devemos fazer uma análise ponderada, pois “isso não quer dizer que a contabilização voltada a regras internacionais deflagra automaticamente consequências tributárias, mas naquilo que a mencionada lei tiver legislado e não autorizado controle distinto para fins fiscais, o registro contábil implica desdobramentos fiscais ${ }^{5}$.

Diante deste contexto é que temos a introdução do artigo 33 da Lei $\mathrm{n}^{\circ}$ 12.973/14, versando sobre "Pagamentos Baseados em Ações”, in verbis:

\footnotetext{
${ }^{5}$ LIBERTUCI, Elisabeth Lewandowski; VITO, Mariana Neves; SOUZA, Luciana Simões. Stock Options e Demais Planos de Ações. Quesões Tributárias Polêmicas e a Lei 12.973/2014. Revista dos Tribunais, São Paulo, 2015. p.131
} 
"Art. 33. O valor da remuneração dos serviços prestados por empregados ou similares, efetuada por meio de acordo com pagamento baseado em ações, deve ser adicionado ao lucro líquido para fins de apuração do lucro real no período de apuração em que o custo ou a despesa forem apropriados.

$\S 1^{0}$ A remuneração de que trata o caput será dedutível somente depois do pagamento, quando liquidados em caixa ou outro ativo, ou depois da transferência da propriedade definitiva das ações ou opções, quando liquidados com instrumentos patrimoniais.

$\S 2^{\circ}$ Para efeito do disposto no $\S 1^{\circ}$, o valor a ser excluído será:

I - o efetivamente pago, quando a liquidação baseada em ação for efetuada em caixa ou outro ativo financeiro; ou

II - o reconhecido no patrimônio líquido nos termos da legislação comercial, quando a liquidação for efetuada em instrumentos patrimoniais.”

Quando lemos o artigo 33 da Lei $n^{0}$ 12.973/14, acima transcrito, nos dá a ligeira impressão de que já vimos esse texto antes. E de fato isso já ocorreu! O referido artigo, representa assim a introdução no ordenamento tributário das orientações contidas no CPC 10, no tocante ao "Pagamento Baseado em Ações”.

Conclui-se assim, que as normas contidas no CPC 10, e reproduzidas no ordenamento tributário por meio da Lei $n^{0} 12.973 / 14$, através de seu artigo 33, só deverão ser fielmente seguidas quando a empresa considera que a entrega de ações se dá para fins de mensurar a prestação de serviços realizados por seus empregados (em suas mais amplas categorias).

Logo, pelas regras contábeis contidas em ambas as normas supracitadas, a mensuração dos serviços se dá ao passe que estes vão sendo prestados, sendo utilizados como mecanismos patrimoniais de liquidação, desde que verificadas as condições estabelecidas para o pleno exercício do direito.

O “Grant Period”, representa o período de concessão ou outorga do direito de adquirir ações, e durante sua vigência, a mensuração serve mais como um norte, representando uma provisão para fins fiscais, a fim de configurar como um valor que representa a despesa advinda de prestação de serviço considerada praticamente já ocorrida, ou com grande possibilidade de ocorrência.

O artigo 33 da Lei $n^{0}$ 12. 973/14 foi ainda, regulamentado pelo artigo 76 da Instrução Normativa RFB $\mathrm{n}^{0} 1.515 / 14$ no que diz respeito aos 
critérios de dedutibulidade para as situações em que a empresa entrega ações aos seus empregados como forma de pagamento por seus serviços prestados. Como poderemos verificar mais para frente, aqui não houve nenhuma imposição quanto a entrega de ações ser pelo preço de mercado, nem mesmo a impossibilitou que a entrega fosse feita por outros motivos que não remuneratórios.

Nestes últimos casos, a possibilidade de manter o contrato mercantil com os empregados, apenas têm caráter indedutível para o Imposto de Renda da Pessoa Jurídica (IRPJ) e Contribuição Social Sobre o Lucro Líquido (CSLL).

É certo dizer que a dedutibilidade que trata o artigo 33 da Lei $\mathrm{n}^{\mathrm{o}}$ 12.973/14 somente deve ser levanta em consideração quando as ações são concedias aos empregados com o objetivo de retribuir pelos serviços prestados. O que as empresas encontram maior dificuldade quando do registro da dedutibilidade, muito tem a ver com a mensuração a ser atribuída a serviços futuros, que somente serão de fato computados se implementadas as condições prefixadas.

O grande problema é que quando a empresa brasileira entende estar sujeita ao que dispõe o artigo 33 da Lei $\mathrm{n}^{\circ}$ 12.973/14, regulamentada pelo artigo 76 da IN RFB $\mathrm{n}^{\circ}$ 1.515/14, a grosso modo, reconhece ao fisco estar efetuando pagamentos a seus empregados por meio de ações.

Em decorrência disso, várias discussões surgem a respeito. Discussões estas que serão abordadas nos capítulos seguintes, e dentre elas estão: (i) se o custo ou despesa incorrido pela empresa serve como base de cálculo para incidência previdenciária; e (ii) se aquilo que foi reconhecido como redutível pela empresa é o que deve ser tributado na pessoa física do beneficiário.

Portanto, a previsão acerca do aproveitamento da dedutibilidade trazida no artigo 33 da Lei $\mathrm{n}^{\circ} 12.973 / 14$, traz muitas consequências para o plano concreto, implicando inclusive no completo afastamento da natureza mercantil/negocial dos planos baseados em ações. 


\section{CAPÍTULO 3. PLANOS DE OPÇÃO DE AÇÃO}

\subsection{Planos de Opções}

Como já vimos no início deste estudo, os planos de opções de ações começaram a aparecer mais em cena quando da necessidade das empresas em manterem seus empregados interessados em permanecer nos quadros da empresa.

Logo, funcionam como balizas estabelecidas pelas empresas, delimitando as condições que os empregados devem atender para poderem adquirir o direito a compra de ações. Ademais, é sempre bom salientar que todos os planos de ações passam por aprovação da assembléia geral da companhia.

Os planos de opções de ações possibilitam, assim, que os empregados possam adquirir opções de compra de ações a preços e prazos determinados. Na maioria das vezes as principais condições estabelecidas a serem cumpridas são: atingimento de metas pelo empregado e que ele permaneça na empresa por determinado tempo sem poder vender as ações, dentre outras.

Segundo Adriana Calvo, “o plano de opção de ações permite que o empregado tenha uma participação na valorização futura da empresa. O intervalo de tempo entre a atribuição das opções e a compra de ações transforma o plano em típico sistema de remuneração diferida, na medida em que se recebe as opções de ações não pode dispor imediatamente do valor potencial dessa remuneração”. ${ }^{6}$

A autora complementa ainda dizendo que dois grandes objetivos são alcançados quando da prática dos planos de ações e seriam eles: (i) a permanência na empresa dos empregados considerados “talentos”, e (ii)

\footnotetext{
${ }^{6}$ CALVO, Adriana. A natureza jurídica dos planos de opções de compra de ações no direito do trabalho - ('employee stock option plans'). Disponível em: <http://www.calvo.pro.br/>. Acesso em 29 de out 2015.
} 
resultados favoráveis através da aliança acionistas e empregados. É o que podemos identificar como relação ganha-ganha no ambiente de trabalho.

O mercado atual é muito dinâmico e frenético, o que permite que cada sociedade avalie suas peculiaridades no momento de escolher qual modalidade de Planos de Ações adotar. Dentre as mais utilizadas temos: (i) Stock Options (SOP); (ii) Restricted Stock United (RSU); (iii) Employee Stock Purchase Plans (ESPP); e (iv) Phantom Stock.

Passaremos então a analisar rapidamente cada uma delas, lembrando que o foco do presente estudo é o Plano de Ações baseado nas Stock Options.

\subsubsection{Stock Options (SOP)}

Relembrando rapidamente o histórico do sistema de compra de ações conhecido como Stock Options, temos que este surgiu inicialmente nos Estados Unidos na década de 50, ganhando força na Europa nos anos 70 e finalmente chegando ao Brasil no final dos anos 80 e início da década de 90, quando de fato passou a ser utilizado por grandes empresas espalhadas pelo mundo.

Segundo Alice Monteiro de Barros, Stock Options "não se identificam com a poupança salarial. O regime das Stock Options permite que os empregados comprem ações da empresa em um determinado período e por preço ajustado previamente". ${ }^{7}$

Sendo assim, podemos afirmar que Stock Options consiste em um direito outorgado aos empregados de comprar ações por um preço e prazo determinados. Nesse sentido, Adriana Calvo leciona:

\footnotetext{
"O sistema de Stock Options consiste no direito de comprar lotes de ações por um preço fixo dentro de um prazo determinado. A empresa confere ao seu titular o direito de, num determinado prazo, subscrever ações da empresa para a qual trabalha ou na grande maioria da sua controladora no exterior, a um preço
}

\footnotetext{
${ }^{7}$ BARROS, Alice Monteiro. Curso de direito do trabalho. São Paulo: Ed. LTR, 2010. p. 783.
} 
determinado ou determinável, segundo critérios estabelecidos por ocasião da outorga, através de um plano previamente aprovado pela assembléia geral da empresa.

Em geral, o plano de stock options contém os seguintes elementos: (1) preço de exercício - preço pelo qual empregado tem o direito de exercer sua opção (exercise price); (2) prazo de carência - regras ou condições para o exercício das opções (vesting) e; (3) termo de opção - prazo máximo para o exercício da compra da ação (expiration date). O preço de exercício é o preço do mercado da ação na data da concessão da opção, sendo comum estabelecer-se um desconto ou um prêmio sobre o valor de mercado.”

A Lei das S/A traz em seu Artigo 168, $\S 3^{\circ}$ a possibilidade de criação de Stock Options. Em síntese, o dispositivo em questão estabelece como requisitos essenciais para sua criação: (i) previsão estatutária de possibilidade de outorga de opção de compra de ações e referente ao limite o capital autorizado para tal; (ii) estabelece os destinatários como sendo os administradores, empregados ou pessoas naturais que prestem serviços à companhia; e (iii) aprovação do plano pela assembléia geral da empresa.

Quanto ao benefício econômico do plano, este é calculado através da diferença entre o valor de mercado das ações e o preço de aquisição. Isso por si só já representa um risco para o empregado, tendo em vista que as ações podem desvalorizar em momento futuro, acarretando em grande desvantagem ao adquirente.

O risco é de fato observado na medida em que o empregado pode exercer o direito de aquisição por determinado valor e à época da venda não obter o retorno do investimento realizado. Deste modo, somente torne-se palpável o efetivo benefício adquirido pelo empregado na concessão das stock options à época da venda das ações então adquiridas.

\subsubsection{Restricted Stock Units (RSU)}

Podemos definir esse plano, como a concessão de ações quando do atingimento das condições preestabelecidas (vesting conditions), que geralmente ocorre após o período de maturação (vesting period), que é o período em que o beneficiário ainda não pode exercer as opções de ações a ele outorgadas. 
Aqui, a concessão das ações está vinculada às condições previamente acordadas entre a companhia e o beneficiário. O resultado do atendimento destas condições pode ter como resultado a concessão de ações ao beneficiário ou o equivalente em dinheiro. Mesmo depois de acordadas e cumpridas as condições para concessão de ações, é comum a utilização do que chamamos de lock up, que consiste em uma restrição temporal para negociação das ações.

Diferentemente das Stock Options, os planos que envolvem as Restricted Stock Units não ensejam em risco para os beneficiários, tendo em vista que este recebe um valor, seja ela em forma de ações ou em espécie, sem qualquer vínculo com seus investimentos.

Quanto à mensuração do benefício econômico, temos duas situações distintas: (i) quando o beneficiário recebe o valor em ações; e (ii) quando recebe o valor em dinheiro. No primeiro caso, nada difere das Stock Options, tendo em vista que o benefício económico somente será mensurado no momento de venda das ações pelo beneficiário. Já na segunda hipótese, quando a pessoa física recebe o montante em espécie, este será o benefício econômico automático resultante.

\subsubsection{Employee Stock Purchase Plans (ESPP)}

Este modelo de plano de ações funciona através de deduções regulares da "Folha de salários" dos empregados, servindo o valor acumulado para a aquisição de ações da própria empresa. Os referidos descontos são feitos entre o período de concessão e o período de exercício.

Assim, o ESPP pretende viabilizar a aquisição de ações por parte dos empregados da empresa, através de um acúmulo sistemático, reservando o montante que será posteriormente utilizado na aquisição de ações, funcionando assim como uma espécie de fundo para investimento.

Com relação ao preço de aquisição de ações, temos que nesta modalidade, em regra, aplica-se uma desconto preestabelecido sobre o valor 
de mercado das ações em um determinado período. Logo, tendo o beneficiário optado por exercer o direito de compra pelo preço previamente acordado, a empresa utilizará o montante por ele acumulado através dos descontos para entregar o correspondente em ações.

Conclui-se assim, que o benefício econômico aqui obtido é o valor que o beneficiário obtém quando da venda das ações advindas do "fundo de investimentos” por ele realizado.

\subsubsection{Phantom Stock}

O Phanthom Stock é um plano geralmente utilizado pelas sociedades anônimas de capital fechado, ou que não têm interesse em negociar ações no Mercado Mobiliário. Isto porque, consiste na outorga de um direito para que no futuro, o empregado receba um montante vinculado ao valor de mercado das ações da empresa em um certo período.

Ou seja, em outras palavras, o beneficiário não recebe o direito de poder adquirir ações a determinado preço e tempo, e sim, o direito ao recebimento em dinheiro em determinado período ou condicionado a evento futuro, do montante correspondente ao valor das ações/quotas da sociedade, de acordo com regras prefixadas.

Em regra, não há risco para o beneficiário, tendo em vista a inexistência de qualquer investimento por parte do beneficiário para o recebimento do montante equivalente ao valor das ações da empresa.

Conforme os ensinamentos de Leornardo José Muniz de Almeida e Maurício Pereira Faro:

“ No Phantom Stock (...) diferentemente da modalidade clássica, o exercício da opção não é feito com a compra das ações. Nesse caso, a empresa emissora das ações paga ao empregado a diferença entre o valor de mercado das ações e o valor da outorga das mesmas, antecipando uma potencial revenda que o participante faria das ações outorgadas. Esse valor pago ao participante é geralmente considerado como remuneração (tem natureza salarial, no caso de ele 
ser empregado) e é tributado pelo Imposto de Renda como rendimento, segundo a tabela progressiva”. ${ }^{8}$

Devemos então fazer a seguinte consideração: no Phantom Stock o beneficiário recebe efetivamente o montante em dinheiro correspondente ao valor de mercado das ações da empresa. Portanto, esse valor ao ser recebido em dinheiro, e não por outros instrumentos patrimoniais, é considerado o benefício econômico obtido pela pessoa física do beneficiário.

Podemos concluir estabelecendo que o que difere o plano baseado em Restricted Stock Units e o Phantom Stock é a titularidade das ações. No primeiro, a titularidade passa ao beneficiário no momento em que este recebe as ações. Já no último, a titularidade as ações não muda, pois estas permanecem com a empresa, recebendo o beneficiário apenas o valor correspondente ao que elas valem no mercado mobiliário.

\subsection{Etapas do plano de opções}

\subsubsection{Aprovação do plano de opções}

Como não poderia deixar de ser, a primeira etapa do plano de ações consiste na aprovação do plano de opções de ações. Isto porque, é nesta etapa em que a Assembléia Geral promove votação dos acionistas, estabelecendo diretrizes, balizas, para sua implementação.

Após a aprovação do plano, este deve ser divulgado a todos os empregados que dele farão parte. A ciência por parte dos empregados é imprescindível, uma vez que é neste momento que o funcionamento, peculiaridades, direitos e deveres são estabelecidos entre eles e a companhia.

\footnotetext{
${ }^{8}$ FARO, Maurício Pereira; ALMEIDA, José Muniz. Tratamento dos Planos de Stock Options após o CPC 10. In: ROCHA, Sergio André. Direito Tributário, Societário e a reforma da Lei das S/A Alterações das Leis nº 11.638/07 e 11.941/09. São Paulo: Quartier Latin, 2010. vol 2.
} 
Sendo assim, somente por meio de um acordo formal estabelecido entre as partes é que se pode dizer que o plano de fato está valendo, podendo de fato dar início ao plano de opções acordado.

\subsubsection{Concessão da opção (grant date)}

Nesta etapa, ocorre efetivamente a outorga do direito à opção de compra de ações da companhia aos empregados. Ainda, é firmado outro entre a companhia e o empregados, em que ambas as partes estabelecem termos relativos às metas e condições da remuneração baseada em ações.

É nesse momento ainda, que a empresa assume a responsabilidade pela emissão dos títulos patrimoniais, sejam eles ações ou opções de ações, ou até mesmo pela transferência de ativos para o empregado participante do plano em curso. Lembrando que tudo sempre está condicionado ao atingimento de metas preestabelecidas no momento da aprovação do plano pela Assembléia Geral.

Vale frisar aqui, que a data da concessão da opção (grant date) pode ser a mesma ou não da data de início dos serviços prestados pelo empregado.

\subsubsection{Data de início do serviço (service incenption date)}

Entende-se por data de início de serviço, aquela em que o empregado inicia suas atividades prol do atendimento das metas preestabelecidas quando da aprovação do plano.

Podemos então concluir, que é a partir do "service incenption date" que de fato o empregado passa a ter direito ao benefício acordado, ou ser afetado de forma adversa pelas alterações/ variações no que se refere ao preço da ação da companhia.

\subsubsection{Período de aquisição de direitos}


Diferentemente da data de início do serviço, o período de aquisição de direitos consiste no período em que o serviço é prestado pelo empregado, com o objetivo de receber a remuneração baseada em ações.

Em outras palavras, podemos dizer que é o período de tempo entre a data de início do serviço até a aquisição efetiva dos direitos concedidos e estabelecidos no plano de opção de ação.

O empregado neste momento apenas adquire o direito, porém ainda não pode exercer as opções. Isto porque, um dos pilares do plano de opções é justamente a retenção do "talento” (empregado) na empresa para que se obtenha o resultado planejado.

\subsubsection{Período de carência do maturação (vesting veriod)}

Ao adquirir os direitos, pressupõe-se que os empregados atingiram as metas preestabelecidas no plano de opções, chegando-se ao resultado desejado devido ao seu trabalho empenhado. Deste modo, o empregado passa a ter a expectativa de exercer seu direito a opção.

Porém, de fato, somente haverá expectativa. Isto porque, conforme os ensinamentos de Adriana Calvo ${ }^{9}$, “a carência (vesting) é o prazo para a obtenção da elegibilidade do exercício das opções. A definição da carência deve variar de acordo com os objetivos da companhia. Se o interesse da Sociedade é premiar um desempenho passado, o ideal é a carência imediata, ao passo que se o intuito for estimular o desempenho, um programa de carência mais longo seria mais apropriado”.

Ou seja, somente após o “vesting” é que o empregado poderá de efetivamente exercer seu direito. Este período de carência ou maturação é acordado entre as partes antes do plano ganhar valor no plano prático. Em regra, as stock options possuem prazo certo, o empregado não pode exercer o seu direito nem antes nem depois da data agendada (expiration date).

\footnotetext{
${ }^{9}$ CALVO, Adriana. A natureza jurídica dos planos de opções de compra de ações no direito do trabalho - ('employee stock option plans'). Disponível em: <http://www.calvo.pro.br/>. Acesso em 29 de out 2015.
} 
Atualmente, devido a volatilidade do mercado de ações, o preço da ação pode variar, ficando inclusive abaixo daquele inicialmente previsto. Logo, a fim minimizar tal imprevisibilidade, foram elaboradas alguma soluções, como: o repricing (redução do preço de exercício), o cancel/reissue (cancelamento das opções existentes e emissão de novas com preços alinhados ao mercado), o extra-grants (concessão de outro lote de ações) e o replacement (permuta das opções existentes por novas opções).

\subsubsection{Período de exercício da opção (exercise period)}

Consiste finalmente no período em que as opções do empregado estão maduras o suficiente para passar a integrar seu patrimônio ou momento em que o empregado pode subscrever a ação.

Compreende o período entre a aquisição definitiva do direito e a expiration date, ou seja, o termo do plano. Em outras palavras, o exercício da opção deve ser realizado entre a aquisição do direito ao exercício e o prazo de expirações das opções, pois uma vez ultrapassado o mesmo, o empregado perderá o direito de exercer a opcão de compra.

Ainda é neste momento em que o empregado decide que exercerá seu direito no todo ou em parte e avaliará se de realmente estará obtendo ganho pecuniário com a compra das ações da companhia.

\subsubsection{Período de inalienabilidade ou trava (lock up period)}

Nada mais é do que o período de indisponibilidade de venda das ações, compreendido entre o exercício da opção, ou seja, a compra da ação, e sua venda. Logo, as ações adquiridas em razão do exercício de opção de ação madura não podem ser negociadas pelo adquirente.

O prazo de inalienabilidade ou trava deve ser fixado de forma predeterminada, por meio de acordo entre as partes em momento anterior. É 
importante frisar, que a inalienabilidade pode ser parcial no que se refere a venda da ação ou da opção da ação. 


\section{CAPÍTULO 4. REFLEXOS NAS CONTRIBUIÇÕES PREVIDENCIÁRIAS}

\subsection{O conceito de remuneração e seus reflexos previdenciários}

Como vimos até aqui, é possível observar que no Brasil, no que se refere as Stock Options, a legislação ainda é muito esparsa e não específica. No âmbito trabalhista e previdenciário, não é diferente, uma vez que por se tratar de matéria ainda "nova”, ou melhor, pouco debatida, não temos uma legislação específica que disponha sobre os valores recebidos a título de participação em planos de compra ou outorga de ações.

Logo, podemos identificar que as questões referentes aos direitos advindos de planos de ações ainda podem ser consideradas controversas justamente pela ausência de legislação específica regulando regulando a matéria. Porém, nosso legislador estabeleceu a remuneração como base do elemento quantitativo do fato gerador das contribuições previdenciárias. Daí surge a importância de se definir o termo remuneração e estabelecer seus limites.

Sobre a incidência das contribuições previdenciárias, o inciso I, alínea a do artigo 195 da Constituição Federal, dispõe:

"Art. 195. A seguridade social será financiada por toda a sociedade, de forma direta e indireta, nos termos da lei, mediante recursos provenientes dos orçamentos da União, dos Estados, do Distrito Federal e dos Municípios, e das seguintes contribuições sociais:

I - do empregador, da empresa e da entidade a ela equiparada na forma da lei, incidentes sobre: a folha de salários e demais rendimentos do trabalho pagos ou creditados, a qualquer título, à pessoa física que lhe preste serviço, mesmo sem vínculo empregatício; “

Além disso, logo adiante, a Constituição Federal prevê no artigo 201, §11, que “os ganhos habituais do empregado, a qualquer título, serão incorporados ao salário para efeito de contribuição previdenciária e conseqüente repercussão em benefícios, nos casos e na forma da lei”. 
Ainda seguindo as definições acerca da remuneração encontradas em nosso ordenamento jurídico, temos a dos incisos I e III do artigo 22 da Lei 8212/1991, in verbis:

“Art. 22. A contribuição a cargo da empresa, destinada à Seguridade Social, além do disposto no art. 23, é de: $\underline{6}$

I - vinte por cento sobre o total das remunerações pagas, devidas ou creditadas a qualquer título, durante o mês, aos segurados empregados e trabalhadores avulsos que lhe prestem serviços, destinadas a retribuir o trabalho, qualquer que seja a sua forma, inclusive as gorjetas, os ganhos habituais sob a forma de utilidades e os adiantamentos decorrentes de reajuste salarial, quer pelos serviços efetivamente prestados, quer pelo tempo à disposição do empregador ou tomador de serviços, nos termos da lei ou do contrato ou, ainda, de convenção ou acordo coletivo de trabalho ou sentença normativa.

(...)

III - vinte por cento sobre o total das remunerações pagas ou creditadas a qualquer título, no decorrer do mês, aos segurados contribuintes individuais que lhe prestem serviços;"

Por fim, e não menos importante, o artigo 457 da Consolidação das

Leis Trabalhistas traz a seguinte definição:

“Art. 457 - Compreendem-se na remuneração do empregado, para todos os efeitos legais, além do salário devido e pago diretamente pelo empregador, como contraprestação do serviço, as gorjetas que receber.

$\S 1^{\circ}$ - Integram o salário não só a importância fixa estipulada, como também as comissões, percentagens, gratificações ajustadas, diárias para viagens e abonos pagos pelo empregador.

$\S 2^{\circ}$ - Não se incluem nos salários as ajudas de custo, assim como as diárias para viagem que não excedam de $50 \%$ (cinqüenta por cento) do salário percebido pelo empregado.

$\S 3^{\circ}$ - Considera-se gorjeta não só a importância espontaneamente dada pelo cliente ao empregado, como também aquela que fôr cobrada pela emprêsa ao cliente, como adicional nas contas, a qualquer título, e destinada a distribuição aos empregados"

Segundo o Professor Sérgio Pinto Martins, “remuneração é o conjunto de retribuições recebidas habitualmente pelo empregado pela prestação de serviços, seja em dinheiro ou em utilidades, provenientes do empregador ou de terceiros, mas decorrentes do contrato de trabalho, de modo a satisfazer suas necessidades básicas e as de suas famílias”.

Atenta ainda, para o fato de que “a remuneração não se confunde com a indenização, que, no Direito Civil, decorre da reparação de um dano. 
A indenização não tem por objetivo retribuir o trabalho prestado ou a disponibilidade ao empregador". 10

Sendo assim, podemos concluir que para que a verba paga seja considerada como remuneração, deve ser dotada de determinadas características que passaremos a analisar a seguir. Afinal, conforme bem leciona Maurício Godinho Delgado (2011, pág. 666) “(...) a regra geral de que somente terá natureza salarial/remuneratória, no Direito brasileiro, as parcelas retributivas habituais devidas e pagas diretamente pelo empregador ao empregado.

Nessa linha, para que o valor recebido pelo empregado quando advindo do plano de ações seja considerado remuneração, acarretando assim na incidência de contribuição previdenciária, há três principais aspectos a serem analisados, e são eles: inexistência de risco, a reciprocidade e a habitualidade.

\subsubsection{Da inexistência de risco}

Analisando o primeiro aspecto, ou seja, a inexistência de risco, temos que a remuneração deve ser analisada como uma quantia já previamente estipulada, sendo revestida do pressuposto de certeza, ou no mínimo sendo tratada como algo aferível.

Geralmente podemos observar que nos planos de PLR e acordo coletivos isso é mais evidente, fazendo com que o salário e as gratificações adquiridas através de políticas de performance, sejam equiparados a valores quantificados ou quantificáveis, que já fazem parte da expectativa de recebimento por parte dos empregados, seja durante o ano ou no andamento do contrato de trabalho.

Por outro lado, no que se refere a compra de opção de ações, atentando sempre para os casos em que o empregado desembolsa um valor

\footnotetext{
${ }^{10}$ MARTINS, Sergio Pinto. Direito da seguridade social. 32. ed. São Paulo: Atlas, 2012. p. 124.
} 
como forma de investimento, tais valores do benefício por ele recebido, aqui não são quantificados previamente, nem quantificados. Ou seja, o risco já é inerente a atividade, haja vista que o empregado pode ganhar pouco ou mesmo nada, chegando em alguns casos até perder. Além disso, há o risco de nem chegar a exercer seu direito.

Podemos então dizem, que o salário, por todas as suas características e função, não está sujeito as oscilações advindas do mercado de capitais, o que o torna uma fonte extremamente segura para o empregado, uma vez que existe a certeza de seu recebimento ao final do mês (art. 459, CLT) ${ }^{11}$, como contraprestação ao serviço prestado.

Vale ressaltar que as jurisprudências trabalhista e tributária vêm se manifestando no sentido de “direitos atrelados a ações, onde há investimento do empregado, não pode ser considerado como parte da compensação, em razão de sua incerteza (variação no valor de mercado das ações - "base de cálculo especulativa”), pois o empregado pode não auferir ganho como resultado da atribuição do incentivo”"12

Porém, nos casos em que é possível verificar que não houve qualquer investimento por parte do empregado, afastando assim a possibilidade da existência de risco, as decisões têm sido no sentido adverso do entendimento esposado acima. Isto porque, a concessão apenas, livre de investimento por parte do empregado, pode ser equiparada à remuneração, estando assim, sujeita a contribuição previdenciária.

Apesar da jurisprudência caminhar no caminho supracitado, é importante destacarmos o ponto de vista do importante precedente referente ao julgamento do processo $\mathrm{n}^{\circ}$ 0021090-58.2012.4.03.6100, em trâmite

\footnotetext{
11 “Art. 459 - O pagamento do salário, qualquer que seja a modalidade do trabalho, não deve ser estipulado por período superior a 1 (um) mês, salvo no que concerne a comissões, percentagens e gratificações”.

${ }^{12}$ LIBERTUCI, Elisabeth Lewandowski; VITO, Mariana Neves; SOUZA, Luciana Simões. Stock Options e Demais Planos de Ações. Quesões Tributárias Polêmicas e a Lei 12.973/2014. Revista dos Tribunais, São Paulo, 2015. p.32.
} 
perante a $10^{\mathrm{a}}$ Vara Federal da Seção Judiciária de São Paulo ${ }^{13}$, ocasião em que foi proferida decisão favorável ao contribuinte.

O Juiz Federal que conduziu o caso entendeu que apesar de não ter havido desembolso para investimento por parte do empregado, devido a exposição das ações às oscilações do mercado, o mesmo poderia obter tanto lucro quanto prejuízo. Logo, apesar de minimizar os riscos, estes não são totalmente extintos,

Por fim, concluímos que quando da análise do valor quantificado do salário juntamente com a existência de risco para o empregado, aplicado uma máxima inversamente proporcional, qual seja: quanto maior o risco assumido pelo empregado, menor a chance do benefício atrelado a ações seja considerado como remuneração.

\subsubsection{Da reciprocidade}

A remuneração também tem requisito para sua caracterizando, a reciprocidade, que significa dizer que somente obterá o direito de adquirir ações aquele que oferece em troca serviço prestado correspondente.

Logo, os benefícios atrelados à performance individual do empregado, geralmente quando falamos no cumprimento de metas, se apenas analisados por esse prisma, seriam considerados pagamentos realizados por meio de remuneração.

Diferentemente do que podemos concluir quando da análise do pagamento atrelado a ações, porém neste caso, sem manter qualquer vínculo com a performance individual do empregado, onde a reciprocidade não se faria evidente, tendo em vista que não haveria uma contraprestação específica a ser analisada.

Como já citamos anteriormente, o artigo 195 da Constituição Federal prevê que a seguridade social será financiada pelos valores pagos pelo

\footnotetext{
${ }^{13}$ Processo no 0021090-58.2012.4.03.6100, 10ª Vara Federal da Seção Judiciária de São Paulo. Disponibilização no Diário Eletrônico de sentença em 29.10.2013, p. 14-94.
} 
empregador ou tomadores de serviço. A alínea a deste mesmo artigo, completa no sentido de que tais valores serão pagos sobre a folha de salários e demais rendimentos do trabalho à pessoa física do empregado (prestador de serviço).

Conforme dispõe o inciso II do artigo 22 da Lei 8212/91, a contribuição previdenciária pode ser recolhida "sobre o total das remunerações pagas ou creditadas, a qualquer título, durante o mês, aos segurados empregados e trabalhadores avulsos que lhe prestem serviços, destinadas a retribuir o trabalho". (grifou-se)

Ainda, no mesmo sentido, o artigo 28 da mesma lei determina a base de cálculo das contribuições previdenciárias como sendo "a remuneração assim entendida, a totalidade dos rendimentos pagos, devidos ou creditados a qualquer título, durante o mês, destinados a retribuir o trabalho, (...)”. (grifou-se)

Sendo assim, podemos afirmar, que diante das reiteradas disposições legais, a vontade do legislador é que para que haja a obrigatoriedade ao recolhimento das contribuições previdenciárias dois requisitos são imprescindíveis: (i) os pagamentos devem ser realizados para pessoas físicas; e (ii) os pagamentos devem ser realizados em contraprestação ao serviço prestado ou trabalho realizado pela pessoa física.

Deste modo, é possível concluir que os valores pagos pelo empregador ao empregado, sem qualquer conexão com o serviço por ele prestado, ou seja, sem qualquer vínculo com sua performance individual, e sem reciprocidade, não podem dar ensejo a hipótese de incidência de contribuições previdenciárias, tendo em vista que não resta caracterizada como verba remuneratórias.

Nos casos específicos em que há a outorga do direito adquirir de ações, entende-se que por não decorrer da prestação direta do serviço, os argumentos são fortes no sentido de que neste caso os pagamentos não possuem caráter retributivo e sim devido meramente por um livre escolha da empresa, na tentativa de manter seus "talentos". 
Portanto, restando comprovada a inexistência de reciprocidade, resta também comprovada a desnecessidade do recolhimento das contribuições previdenciárias, e por sua vez a não caracterização do fato gerador, que é justamente a retribuição paga pelo serviço prestado.

\subsubsection{Da habitualidade}

O último aspecto, mas não menos importante, é o da habitualidade, ou também conhecida como regularidade dos pagamentos realizados. Conforma dispõe nossa legislação previdenciária, não restam duvidas de que todo pagamento realizado de forma habitual/regular é considerado remuneração, tendo em vista que é uma prestação de trato sucessivo.

Da mesma forma, de acordo com a legislação previdenciária, mais especificamente, com o $\S 9^{\circ}$ do artigo 28, e item 7 da Lei 8212/91 ${ }^{14}$, são excluídos da base de cálculo, os pagamentos de caráter esporádico, pois seriam pagamentos não recorrentes e que não mantêm nenhuma relação com o salário.

Tanto a jurisprudência judicial, quanto a administrativa adotam o entendimento de que os valores recebidos como ganhos não recorrentes e não integram a base de cálculo das contribuições previdenciárias.

Vale apenas ressaltar, que muitas vezes os planos de opções de ações se dão em caráter anual, logo, se for possível comprovar que os benefícios são disponibilizados aos empregados todo ano, poderia de fato enfraquecer o argumento de não habitualidade.

Por isso, é sempre muito importante a análise realizada caso a caso, permitindo uma avaliação minuciosa e adequada, delimitando os limites dos

\footnotetext{
${ }^{14}$ Art. 28. Entende-se por salário-de-contribuição:

(...)

$\S 9^{\circ}$ Não integram o salário-de-contribuição para os fins desta Lei, exclusivamente:

(...)

e) as importâncias:

(...)

7. recebidas a título de ganhos eventuais e os abonos expressamente desvinculados do salário;
} 
direitos sobre as ações recebidos pelo empregado, individualmente, para aí sim determinar se podem ser ou não considerados como remuneração.

\subsection{Da análise específica no Stock Options Plan (SOP)}

A grande discussão analisada tanto pela jurisprudência trabalhista, quanto pela previdenciária/tributária, é aquela que analisa se um plano de outorga de ações possui caráter remuneratório ou mercantil. Veremos, que a conclusão acerca deste tema somente será possível quando da análise minuciosa de caso a caso, como já falamos anteriormente.

Conforme leciona o Modesto Carvalhosa, as opções de compra de ações têm natureza jurídica contratual, conforme conceito utilizado na prática societária norte-americana, que diz:

“A opção de compra reveste-se de natureza contratual e personalíssima (...) constitui contrato preliminar unilateral, celebrado entre a companhia de capital autorizado e os legitimados (empregados, administradores e terceiros contratantes), tendo por objeto a celebração de um contrato de subscrição ou de compra de ações, cuja efetivação dependerá apenas da vontade destes últimos.”15

Ainda sobre à sua natureza jurídica, segundo os ensinamentos do Professor Sérgio Pinto, tal operação também consiste em um ato jurídico de natureza mercantil, ou seja, considera como se fosse um contrato de natureza exclusivamente civil, senão vejamos:

“A natureza jurídica da opção de compra de ações é mercantil, embora feita
durante o contrato de trabalho, pois representa mera compra e venda de ações.
Envolve a opção um ganho financeiro, sendo até um investimento feito pelo
empregado nas ações da empresa. Por se tratar de risco do negócio, em que as
ações ora estão valorizadas, ora perdem seu valor, o empregado pode ter prejuízo
com a operação. É uma situação aleatória, que nada tem a ver com o empregador
em si, mas com o mercado de ações. Não se pode dizer que se trata de um
pagamento dissimulado ou disfarçado com o objetivo de não integração ao
salário, pois o sistema não foi inventado por brasileiros, mas é observado,
principalmente nas grandes corporações americanas. Dessa forma, Não é atraída
a aplicação do art. $9^{\circ}$ da CLT, no sentido de que o empregador teria por objetivo

${ }^{15}$ CARVAlHOSA, Modesto. Comentários à Lei de Sociedades Anônimas. 6 ed. São Paulo: Saraiva, 2014, vol 1. 
desvirtuar, impedir ou fraudar preceitos trabalhistas, principalmente o pagamento de natureza salarial."16

Os elementos da operosidade e do risco ficam evidentes quando do desembolso realizado por parte do empregado, convertido em forma de investimento, o que acaba por reforçar a natureza mercantil do plano, e consequentemente, enfraquecer o caráter remuneratório. Da mesma forma que se o empregado estiver isento de riscos, essa máxima se reverte, ganhando mais força a atribuição do conceito de remuneração.

Sendo assim, é possível observa que a jurisprudência brasileira vem adotando uma posição bem coerente, no sentido de que, como regra geral, as ações fornecidas com desembolso/investimento do empregado, vinculado ao risco, e ainda, quando não pagas sob o requisito da reciprocidade, teriam natureza apenas mercantil e não salarial.

Não podemos esquecer, que de acordo com a jurisprudência e também com a legislação, os principais requisitos que devem estar presentes para que a natureza remuneratória não possa ser afastada são: a inexistência de risco, a reciprocidade e a habitialidade/regularidade.

No caso específico das Stock Options Plans (SOPs), temos que são planos nos quais existe o investimento por parte do empregado, tendo em vista que a outorga das opções é feita de forma a promover o incentivo à permanência do empregado na empresa, bem como realizar investimento na própria companhia, mesmo que essas concessões ocorram de forma habitual.

Ou seja, na grande maioria dos casos em que observamos esse tipo de plano de concessão de ações, o empregado adquire ações de forma onerosa. E é com base nesta situação que a jurisprudência tem corroborado o entendimento de que o fornecimento de SOPs não pode integrar a remuneração do empregado para fins previdenciários, em razão de sua

\footnotetext{
${ }^{16}$ MARTINS, Sérgio Pinto. Natureza do Stock Option no Direito do Trabalho. Suplemento OT Legislação, Jurisprudência e Doutrina, ano XXIV, n. 11, p. 3, São Paulo: Thomson IOB, now 2005.
} 
incerteza, já que o empregado pode auferir ganho ou não, devido as oscilações no valor de mercado das ações.

Podemos então dizer, que há fortes argumentos para a defesa de que a concessão das SOPs quando presentes principalmente o fato de incorrer em risco e investimento por parte do empregado, uma vez que não é garantida a efetivação do benefício, tendo havido desembolso, sem certeza de ganho futuro.

Mais para frente, em tópico específico, iremos mapear o entendimento jurisprudencial tanto na esfera administrativa quanto na judicial, mas por hora, vale destacar, que ambas consideram: quanto maior o risco do negócio, menor o risco tributário, e quanto menor o risco do negócio, maior o risco tributário.

Além disso, assim como nossa legislação, nossa jurisprudência ainda precisa percorrer uma longa jornada para atingir uma maior uniformização e profundidade sobre a matéria. Porém, para que melhor se aplique os conceitos até aqui apresentados, entendo que a melhor forma seja a análise caso a caso.

O Conselho Administrativo de Recursos Fiscais (CARF), vinha decidindo no sentido de que as opções outorgadas pelos contribuintes brasileiros são redutíveis para fins de imposto de renda, quando os montantes são efetivamente pagos em dinheiro ou em espécie aos empregados. Este entendimento foi corroborado e positivado por meio do artigo 33 da Lei 12.973/14.

Ainda em referência à Lei $\mathrm{n}^{\circ}$ 12.973/14, é importante destacar que ela não menciona que stock options ou planos atrelados a ações possuem caráter remuneratório. Por outro lado, determina que quando houver concessões desse gênero, ou seja, a título de remuneração, os valores devem ser computados para fins de dedutibilidade de IRPJ e CSLL na pessoa jurídica, nos moldes da lei. 


\subsection{Da base de cálculo das contribuições previdenciárias e dos valores devidos em caso de autuação fiscal}

Conforme viemos verificando até aqui, no caso em que a concessão dos planos de ações tenham caráter remuneratório, a jurisprudência entende que se faz justificável a autuação. Nesse cerne, temos que para análise da tributação, seus elementos essenciais são: base de cálculo das contribuições previdenciárias, bem como as alíquotas aplicáveis.

Em primeiro lugar, quanto a base de cálculo, há grande divergência e confusão entre os fiscais e os julgadores, tendo em vista que alguns consideram como base de cálculo o valor da ação na data da outorga do direito. Por outro lado, há quem defenda que para fins de contribuição previdenciária a data adotada deveria ser a do vesting. E, por fim, há ainda aqueles defensores da utilização da data do exercício.

Apesar dessas três principais vertentes, o entendimento que vem ganhando espaço (mas que ainda é minoritário), principalmente na jurisprudência é o de que a base de cálculo nestes casos, seria configurada como especulativa, afastando a incidência da contribuição previdenciária. Isto porque, estaríamos diante de uma base de cálculo imprópria, uma vez que fictícia e arbitrária, o que não é admitido no direito tributário brasileiro.

Sendo assim, podemos concluir que quando a outorga for considerada como remuneração, a fiscalização pode se valer dos períodos acima mencionado para estabelecer o valor da ação, e por consequência, estabelecer a base de cálculo das contribuições previdenciárias.

Já com relação ao recolhimento e às alíquotas aplicáveis, vale ressaltar que no que diz respeito as contribuições previdenciárias, essas são devidas tanto pelo empregador, quanto pelo empregado, apesar das regras aplicáveis serem diferentes para cada uma das partes.

Conforme dispõe o artigo 22 da Lei 8212/91, o empregador deve recolher contribuições previdenciárias à alíquota de $20 \%$ sobre a totalidade da remuneração paga aos seus empregados, com algumas exceções previstas em lei. 
Ainda, vale destacar, que o empregador também pode ser enquadrado como o responsável pelo recolhimento de outras contribuições sociais devidas a terceiros, o que pode elevar a alíquota da contribuição previdenciária patronal, podendo chegar a 30\% sobre os valores pagos aos empregados, de adoro com a categoria da empresa.

Porém, no que diz respeito aos empregados, assim considerados os indivíduos para fins previdenciários, ao receberem remuneração decorrente de contraprestação ao serviço realizado, serão tributados de forma $\operatorname{progressiva}^{17}$, cuja variação das alíquotas atualmente é de $8 \%$ a $11 \%$. Apenas lembrando, que apesar de o empregado ser o contribuinte de fato, quem faz a retenção e o recolhimento em seu lugar é o empregador, na condição de substituto tributário.

Atentando especificamente para os casos em que temos planos atrelados a ações integrando a remuneração do empregado, o empregador será obrigado também ao recolhimento de FGTS sobre tais pagamentos, devendo a empresa informar tais valores em GFIP. Além disso, os referidos pagamentos também poderão servir como base de cálculo para a cobrança de demais direitos trabalhistas.

Retomando a discussão quanto a autuação previdenciária, especificamente no Stock Options Plans (SOPs), o fisco poderá exigir o pagamento das contribuições previdenciárias incidentes sobre tais benefícios, quando restar comprovado seu caráter remuneratório, acrescida de multa de 75\% (multa de ofício) e juros (atualizados pela Taxa Selic).

O artigo $138^{18}$ do Código Tributário Nacional prevê o instituto da denúncia espontânea, que afasta a responsabilidade por infrações tributárias. No presente caso, exclui-se a aplicação da multa de 75\%. Ainda

\footnotetext{
${ }^{17}$ O Ministério da Previdência Social publica periodicamente tabela progressiva com a a variação das alíquotas para cada faixa de salário. Em 2015, a faixa máxima é de R \$4.663,75, estando a contribuição do empregado limitada a R \$ 513, 01 por mês.

${ }^{18}$ Art. 138. A responsabilidade é excluída pela denúncia espontânea da infração, acompanhada, se for o caso, do pagamento do tributo devido e dos juros de mora, ou do depósito da importância arbitrada pela autoridade administrativa, quando o montante do tributo dependa de apuração. Parágrafo único. Não se considera espontânea a denúncia apresentada após o início de qualquer procedimento administrativo ou medida de fiscalização, relacionados com a infração.
} 
não é entendimento pacífico, mas, no que concerne a multa de de mora de 20\%, aplicado em razão do atraso no recolhimento da contribuição previdenciária, já há decisões na esfera judicial que também afasta sua aplicação, quando da denúncia espontânea.

Por fim, aplica-se às contribuições previdenciárias a regra prevista no artigo 150, § $4^{\text {o19 }}$ do Código Tributário Nacional, que determina o prazo decadência de cinco anos para a cobrança das contribuições previdenciárias, contados a partir da ocorrência do fato gerador do tributo.

\subsection{Jurisprudência do Conselho Administrativo de Recursos Fiscais (CARF)}

\subsubsection{Caso "Cosan" 20}

Trata-se de auto de infração lavrado com vistas a cobrança de contribuições previdenciárias patronais supostamente incidentes sobre valores negociados nas operações de compra de ações efetuada pelos executivos da empresa conforme estipulado no Plano de Opção de Compra de Ações (Stock Options - SOPs), no período de nov/2006 a dez/2009.

O fisco entendeu que a diferença entre o preço da ação na data da concessão e o preço da ação da data da aquisição seria remuneração diferida paga aos executivos (contribuintes individuais), tendo em vista a ausência de risco na transação, estando portanto, obrigados ao recolhimento de contribuições previdenciárias.

\footnotetext{
${ }^{19}$ Art. 150. O lançamento por homologação, que ocorre quanto aos tributos cuja legislação atribua ao sujeito passivo o dever de antecipar o pagamento sem prévio exame da autoridade administrativa, opera-se pelo ato em que a referida autoridade, tomando conhecimento da atividade assim exercida pelo obrigado, expressamente a homologa.

(...)

$\S 4^{\circ}$ Se a lei não fixar prazo a homologação, será ele de cinco anos, a contar da ocorrência do fato gerador; expirado esse prazo sem que a Fazenda Pública se tenha pronunciado, considera-se homologado o lançamento e definitivamente extinto o crédito, salvo se comprovada a ocorrência de dolo, fraude ou simulação.

${ }^{20}$ (AC 2.301-003.597. Processo Administrativo $\mathrm{n}^{\circ}$ 15889.000245/2010-46. Conselheiro relator Adriano Gonzales Silveira. $1^{\text {a }}$ Turma Ordinária da $3^{\text {a }}$ Câmara da $2^{\text {a }}$ Seção do CARF: Sessão de Julgamento de 20.07.2013).
} 
Quando da análise das Atas de Reunião do Conselho de Administração da Empresa, o auditor fiscal entendeu que o "Plano de Opção de Compra de Ações” configurava como uma remuneração indireta.

Conforme podemos observar abaixo, as "Diretrizes de Elaboração e Estruturação” do supracitado Plano (anexado em Assembléia Geral Extraordinária, em 30.05.2005), estabeleceram como objetivo:

“(a) estimular a expansão, o êxito e os objetivos sociais da companhia e os interesses de seus acionistas, permitindo aos executivos e empregados de alto nível adquirir ações da companhia, nos termos e condições previstas nos planos, incentivando desta forma a integração de tais executivos e empregados na companhia.

(b) possibilitar à companhia a obtenção e a manutenção do serviços de executivos e empregados de alto nível, oferecendo a tais executivos e empregados uma vantagem adicional e oportunidade de se tornarem acionistas da companhia, nos termos, nas condições e no modo previstos nos planos.”

O item 12.4 do "Relatório Fiscal” delimitou os supostos elementos que comprovariam a hipótese de incidência tributária:

“12.4 - No caso em tela, temos os dois elementos requeridos pela Hipótese de Incidência que provam a ocorrência do Fato Gerador:

a) o Crédito Jurídico ocorreu com a outorga pela companhia aos executivos elegíveis, em 22/09/2005, da opção de compra futura de 4.302 .780 ações ao preço fixo de R\$ 6,11 por ação;

b) a Prestação de Serviço à companhia pelos executivos elegíveis ocorreu no período compreendido entre a outorga do direito à opção de compra e o efetivo exercício do direito com a integralização e recebimento das ações, o que ocorreu em 2006, 2007 e 2009 conforme registrado em atas de assembléias e na contabilidade da companhia.”

Nos autos do processo é possível observar o parecer realizado pela Ernest \& Young, responsável pela auditoria contábil, que sugeriu a aplicação das normas contidas no CPC 10, que regulamentou o tratamento contábil a ser dado aos Planos de Opções de Compra de Ações.

Os Conselheiro do Conselho Administrativo de Recursos Fiscais (CARF) se utilizaram do parecer realizado pela Ernest \& Young para justificar que o mesmo ao sugerir a utilização das normas contidas no CPC 10, estaria confirmando o caráter remuneratório das operações realizadas pelos executivos. 
Porém, o fato de as empresas brasileiras serem obrigadas a seguir as normas contábeis dispostas no CPC 10, por si só não seria suficiente para descaracterizar o caráter mercantil das operações envolvendo os Stock Options Plans (SOPs).

Seguindo esse entendimento, vale transcrever o trecho do "voto vencido”, proferido pelo Conselheiro Relator Adriano Gonzales Silvério, que estabeleceu um paralelo de diferenciação entre os tratamentos contábeis e tributários a serem aplicados aos Planos de Ações, in verbis:

“Analisando a clássica operação de "stock option”, é imperioso salientar que, embora o CPC 10 classifique, em geral, "stock options" como espécie de despesas de remuneração, para efeitos de lançamento contábil, em termos jurídicos, o plano de opção de compra de ações, dado o modo pelo qual é instrumentalizado e a finalidade a que se destina, não se enquadra no conceito de remuneração.

Vale ressaltar que há discussão em torno do reconhecimento contábil da "stock options" como despesas de remuneração. Marcos Shigueo Takata, no artigo acima mencionado, revela:

"Sem prejuízo do Direito Contábil posto, ainda há discussão doutrinária sobre tratar o reconhecimento contábil das stock options como despesa da empresa. Sobre isso, iremos abordar mais detidamente no outro tópico. Houve muita discussão a respeito, inclusive quanto à não contabilização das stock options (e não somente quanto a tratar como despesa da empresa o registro contábil), envolvendo inclusive o Congresso norte americano, para que não houvesse o registro contábil "sugerido" pelo FASB. A discussão era (e ainda é) de quem deveria arcar com os ônus do "pagamento baseado em ações" (stock options) se a empresa (acionistas).

10.2 Em resumo, o argumento contrário ao registro contábil é centrado seguinte. O fato de que na outorga de stock options aos executivos não há desembolso de caixa pela empresa, mas apenas o custo de oportunidade para ela, na medida em que ela receberá (se exercidas as stock options) menos do que ela poderia obter se colocasse as ações (distribuições), no exercício das stock options, i. e., menos do que valeriam as ações. E, por outro lado, os ônus dos acionistas são evidentes, pois é fato que há diluição da participação deles, com a "entrada" de novos acionistas, com o exercício das stock options, e que se dá por valor inferior ao que as ações valem nesse momento."

Sem prejuízo dos posicionamentos acima citados, entendo que a regulamentação contábil não interfere na natureza jurídica do instituto, bem como no seu tratamento perante as contribuições previdenciárias.”

Já o voto vencedor, proferido pelo Conselheiro presidente Marcelo Oliveira, no que diz respeito ao conceito de remuneração, podemos observar a adoção e um entendimento mais abrangente, onde tudo que gera 
ganho ao empregado (ou contribuinte individual) deve ser considerado para composição da base de cálculo das contribuições previdenciárias.

Isto porque, o Conselheiro presidente entendeu que as SOPs representariam um ganho evidente por parte do empregado, tendo em vista que nenhuma empresa de capital aberto teria como meta a desvalorização de suas ações. Além disso, sustentou que o ganho era evidente pois a modalidade utilizada seria o cashless, o que afastaria o risco do negócio e o fato de haver preço predeterminado.

Para que fosse considerado negócio mercantil, de acordo com o entendimento da $1^{\mathrm{a}}$ Turma Ordinária da $3^{\mathrm{a}}$ Câmara da $2^{\mathrm{a}}$ Seção do CARF, seriam necessários os requisitos mencionados no trecho abaixo, retirado da decisão:

"Feitas essas considerações, necessitamos analisar o que são "stock options (SO)”.

SO são operações financeiras nas quais são comercializadas opções de compra de ações de empresas, por um preço preestabelecido, que deverão ser exercidas em certo prazo.

Ou seja, o comprador adquire, paga, por um direito de comprar a ação por um certo e definido preço, após um certo período.

Caso a soma do valor gasto com o direito, mais o valor definido seja menor do que o valor da ação na data estipulada, o comprador da SO pode exercer seu direito e obter um ganho financeiro, seja pela venda da ação, seja pelo aumento de patrimônio, na manutenção da ação.

Ao contrário, caso, por exemplo, na data estipulada e definida, as ações apresentem valor inferior ao definido somado ao que foi pago pelo direito de compra, a opção de compra não é exercida, pois gerará prejuízo, já que será pago valor maior do que o exercido pelo mercado naquela data.

Lucro ou prejuízo, sim, são características que podem ocorrer em um negócio mercantil.

Para as empresas há interesse nas SO, pois estreita a relação entre empresa e segurado.

Para o segurado a facilidade reside em transacionar diretamente com a empresa, ser parte na variação do valor das ações, realizar aplicação financeira, auxiliar no aumento do valor patrimonial da empresa.

Portanto, para que as SO não tenham caráter remuneratório há requisitos a serem cumpridos, como a incerteza, o risco, comum nas aplicações financeiras, sejam quais forem.

No presente caso, as regras de mercado não foram seguidas, não se trata de investimento do segurado, pois as SO não foram adquiridas, mas sim outorgadas, concedidas, dadas, como deixa claro o documento intitulado "Diretrizes de Elaboração e Estruturação de Plano de Opção de Compra de Ações”, assim como deixa claro qualquer documento nos autos sobre o pagamento de tais direitos pelos segurados citados. 
Portanto, há o primeiro ganho dos segurados, não pagar, ser isento em adquirir um direito, que é, aliás, negociado pelas empresas de capital aberto e devidamente tributado, pelo Fisco.

Outro ponto interessante, que evidencia o ganho, é que o valor futuro definido não pode, como no plano em questão, ser menor do que o valor atual, na data da concessão, pois nenhuma empresa de capital aberto tem como meta a perda do valor de suas ações.

Em constando essa característica, como no presente caso, há prova de um benefício dado, com a anulação do risco, seja por receber gratuitamente a SO, seja pela ausência de lógica de uma empresa apontar que o valor da ação pode vir a ser menor do que o valor ofertado ao segurado para adquirir no futuro.”

\section{Ocorre que, entendo estar mais de acordo com o que expôs o}

Conselheiro Adriano Gonzales Silvério, quando faz referência a não relação

existente entre o recebimento de ação e a contraprestação pelo trabalho

realizado, no caso concreto. Segue mais um trecho de seu "voto vencido", em que bem afasta a referida relação:

"Embora o conceito de remuneração seja amplo, de modo a abranger o pagamento a qualquer título para recompensar o serviço prestado pelo segurado, não há como admitir, pelo próprio conceito do "stock option plan", na sua modalidade tradicional, tal como a verificada nos autos, seja considerado remuneração, haja vista que a relação jurídica fixada entre os sujeitos de direito, quais sejam, empresa e segurado é diametralmente oposta àquela albergada pelas contribuições.

A relação jurídica objeto das contribuições é aquela em que a empresa tem o dever de pagar remuneração e o direito de exigir a prestação de serviços, sendo que o segurado tem o dever de prestar os serviços e o direito de receber a remuneração devida. No entanto, no âmbito do plano de opção de compra de ações, o segurado tem o direito de comprar ou não as ações e, caso opte por exercê-lo, efetuará o pagamento à empresa proporcionalmente ao volume de ações adquiridas, ao preço fixado no plano.

Nessa situação, a empresa tem o direito de receber o pagamento pelas ações e dever de entregá-las ao segurado, enquanto que este terá o dever de pagar pelas ações e o direito a recebê-las em sua órbita patrimonial.

É importante salientar que, da perspectiva do segurado, essa transação não é vista como recompensa do seu trabalho prestado, pois, embora compre as ações a preço pré estabelecido e em valor menor ao que é negociado no mercado, não deixa de se submeter ao risco do negócio, ou seja, não só de não obter a rentabilidade esperada, como também perder o que investiu.

(...)

O Professor Fábio Ulhoa Coelho, em sua obra Curso de Direito Comercial, vol. 2., Saraiva, pag. 170, demonstra minudentemente o negócio jurídico entabulado entre as partes na órbita do "stock options plan":

“(...) Trata-se de negócio jurídico, pelo qual a companhia se obriga, a partir da declaração de vontade do executivo beneficiário (exercício da opção) $e$ pagamento por este preço, a entregar-lhe ações de sua emissão, em quantidade $e$ espécie previamente definidas no instrumento de opção."

De fato, o plano de opção de compra de ações aqui analisado é uma relação jurídica típica de direito civil, a qual tem por objeto permitir que o segurado exerça ou não uma faculdade de adquirir ações da empresa, após ultrapassado o 
período de carência e mediante o pagamento de preço, não envolvendo a troca de prestação de serviços por remuneração, embora ocorrido no curso da relação de trabalho.

(...)

Aprofundando nessa temática e em atenção ao caso desses autos, enquanto o plano de opção de compra de ações, quando exercido o direito de compra, teve por objeto uma obrigação de dar, uma vez que o segurado entregou dinheiro em troca de ações, a relação jurídica inserida no contexto das contribuições previdenciárias, tem por natureza contraprestacional uma obrigação de fazer.

Tal fato revela que as relações jurídicas são completamente distintas e interdependentes, não havendo qualquer conexão entre ambas.

(...)

Não se configura a natureza salarial da parcela quando a vantagem percebida está desvinculada da força de trabalho disponibilizada e se insere no poder deliberativo do empregado, não se visualizando as ofensas aos arts. 457 e $458 \mathrm{da}$ CLT."

Ainda, o Conselheiro relator verificou que a base de cálculo das contribuições previdenciárias supostamente incidente sobre SOPs seria especulativa em razão da oscilação dos valores das ações no mercado mobiliário.

Como já vimos, o direito tributário brasileiro não admite base de cálculo especulativa, por se tratar de uma base de cálculo fictícia e arbitrária. Dessa forma, ato jurídico que supostamente daria causa à hipótese de incidência tributária, não seria aperfeiçoada, tendo em vista que o “ganho” nem sempre pode ser efetivo, resultando também em “perda” por parte dos executivos, caso as ações desvalorizassem futuramente (no momento da efetiva venda das ações).

Sobre esse entendimento, segue a parte final de seu voto:

“Ademais, não posso deixar de manifestar a minha preocupação com a forma como foi determinada a base de cálculo das contribuições previdenciárias no caso concreto, a qual resultou da diferença existente entre o valor da ação no mercado, no momento em que foi exercida a opção de compra e o valor de aquisição pelos segurados.

O problema dessa sistemática é que além de, na minha visão, não ter ocorrido o fato gerador das contribuições, a base de cálculo é especulativa, pois além de não confirmar a relação jurídica tributária, já que essa não ocorreu, toma por base uma expectativa futura de ganho, o qual pode ou não ocorrer, já que depende de posterior alienação das ações por parte do segurado e que estas sejam avaliadas no mercado por valor acima daquele pago quando da aquisição.

Outro dado importante a ser avaliado é que o aumento ou a diminuição da diferença enquadrada como "remuneração" não está atrelada à prestação de serviços do segurado, mas sim à cotação das ações no mercado, o que demonstra a completa interdependência das relações jurídicas outrora analisadas. E, o valor 
recebido na venda, não é pago pela empresa, mas por terceiro que adquiriu as ações.”

Após análise de inteiro teor da decisão, é possível verificar, que infelizmente, a questão sobre a base de cálculo especulativa não foi sequer enfrentada pelos demais Conselheiros.

Contudo, apesar da decisão ter sido desfavorável ao contribuinte, esta não foi unânime, o que já representa um grande avanço, tendo em vista que o resultado final foi alcançado apenas após o voto de qualidade do presidente da $1^{\text {a }}$ Turma Ordinária da $3^{\mathrm{a}}$ Câmara da $2^{\mathrm{a}}$ Seção do CARF.

Atualmente, a discussão referente a este caso concreto ainda não se encerrou na esfera administrativa, uma vez que está pendente de julgamento o Recurso Especial interposto pelo Procurador e os Embargos de Declaração opostos pela Cosan.

\subsubsection{Caso "ALL"21}

No presente caso, há de se esclarecer que foram proferidos dois acórdãos tratando sobre a mesma matéria. Porém, para melhor aprofundarmos o presente estudo, iremos nos ater ao acórdão $\mathrm{n}^{0}$ 2401003.044, tendo em vista sua maior abrangência sobre o assunto, além de ser mais detalhado.

Assim como no caso da Cosan, acima descrito, trata-se de autos de infração lavrados com vistas ao reconhecimento das contribuições previdenciárias patronais supostamente incidentes sobre valores negociados nas operações de compra de ações, conforme estipulado no Plano de Opção de Compra de Ações (Stock Options - SOPs).

\footnotetext{
${ }^{21}$ (AC 2401-003.044. Processo Administrativo $\mathrm{n}^{\circ}$ 10980.724030/2011-33. Conselheira Relatora Elaine Cristina Monteiro e Silva Vieira. $1^{\mathrm{a}}$ Turma Ordinária, da $4^{\mathrm{a}}$ Câmara da $2^{\mathrm{a}}$ Seção do CARF. Sessão de Julgamento: 18.07.2013).

(AC 2401-003.045. Processo Administrativo $\mathrm{n}^{\circ}$ 10980.724031/2011-88. Conselheira Relatora Elaine Cristina Monteiro e Silva Vieira. $1^{\mathrm{a}}$ Turma Ordinária, da $4^{\mathrm{a}}$ Câmara da $2^{\mathrm{a}}$ Seção do CARF. Sessão de Julgamento: 18.07.2013).
} 
Ainda, os referidos autos pretendiam a cobrança de multa isolada pelo descumprimento da obrigação acessória correlata, referente ao período compreendido entre jan/2006 e dez/2008.

De acordo com o "Relatório Fiscal”, o "Plano de Opção de Compra de Ações” instituído pela empresa por si só já traria os elementos e pressupostos que comprovariam a hipótese de incidência tributária:

15) A empresa criou "Plano de Opção de Compra de Ações", aprovado pela Assembléia Geral de 01 de abril de 1999 (fls. 69/75). O Plano é administrado por um Comitê composto especificamente para este fim que periodicamente cria "Programas de Opção de Compra de Ações". Os Programas têm por objeto a aprovação do modelo de "Contrato de Oferta à Subscrição ou Compra a Termo de Ações e Outros Pactos”, definindo, dentre diversas questões, os Beneficiários, a quantidade de opções outorgadas a cada Beneficiário e o valor e a forma de contribuição para aquisição das ações. A Empresa instituiu Programas anualmente entre 1999 e 2010, com exceção de 2002 e 2004. Os Programas de 2007 e 2008 foram cancelados em 03 de agosto de 2009 e os Beneficiários tiveram as suas opções trocadas por opções do Programa 2009, em condições de exercício mais favoráveis ao cenário econômico da época.

16) Os Programas são aprovados pelo Comitê de Administração do "Plano de Opção de Compra de Ações", o qual aprova também os modelos de "Contrato de Oferta à Subscrição ou Compra a Termo de Ações e Outros Pactos", "Relação de Beneficiários Indicados pela Diretoria da Companhia", e modelos de "Contrato de Empréstimo", os quais passam a fazer parte integrante do Programa. As "Relações de Beneficiários" dos diversos Programas foram tabuladas na "Relação de Beneficiários do Plano de Opção de Compra de Ações” (fls. 710/716), na qual podemos observar a distribuição das concessões de outorga entre os Beneficiários.

(...)

18) A empresa esclarece que o "Plano de Opção de Compra de Ações" é uma vantagem adicional concedida a seus colaboradores com a finalidade de compor, motivar e manter o seu quadro. O "Plano de Opção de Compra de Ações" é gerido por um Comitê que define quem serão os Beneficiários e a quantidade de ações que cada Beneficiário poderá subscrever. O Comitê tem autonomia para dar tratamento diferenciado aos Beneficiários conforme suas atribuições e desempenho. O Anexo V da Ata da Assembléia Geral Extraordinária de 10 de abril de 1999 ("Plano de Opção de Compra de Ações”) esclarece:

a) A empresa reconhece como objetivo do "Plano de Opção de Compra de Ações" criar uma vantagem adicional oferecida a administradores, empregados e profissionais com a finalidade de atraí-los e mantê-los a seu serviço (item "1.b" do "Plano de Opção de Compra de Ações");

b) O "Plano de Opção de Compra de Ações" é administrado pelo Conselho de Administração da empresa ou por um Comitê eleito especificamente para este fim, o qual pode "tratar de maneira diferenciada Beneficiários que se encontrem em situação similar, não estando obrigado, por qualquer regra de isonomia ou analogia, a estender a outros Beneficiários qualquer condição ou deliberação que 
entenda aplicável apenas a um ou mais Beneficiários determinados (itens "2.a” e "2.e" do "Plano de Opção de Compra de Ações”)";

c) O Comitê cria os "Programas de Opção de Compra de Ações”, definindo "as pessoas a quem serão outorgadas opções de fazer contribuições para aquisição de ações no âmbito do Plano (os "Beneficiários")" e o "número de ações que os Beneficiários terão direito de subscrever com o exercício da opção (itens "2.1.a" e "2.1.b” do "Plano de Opção de Compra de Ações”)";

d) "O Comitê escolherá, para cada Programa, aqueles que farão jus à outorga da opção, conforme as atribuições, responsabilidades e/ou desempenho de cada um" (item 3 do "Plano de Opção de Compra de Ações").

19) Os "Programas de Opção de Compra de Ações", tanto nos Contratos Modelo “A” quanto nos Contratos Modelo "B” prevêem que o beneficiário deve efetuar o pagamento de $10 \%$ do valor das ações, no ato da assinatura do contrato, como condição para aquisição do direito à opção de compra de ações. Este ônus é afastado pela concessão feita pela empresa aos Beneficiários de empréstimo para quitação desta obrigação, conforme abaixo:

20) Por ocasião da Crise Financeira Internacional de 2008, os "Programas de Opção de Compra de Ações” 2007 e 2008 ficaram, a partir de certo momento, com o preço de exercício superior ao preço de mercado. O Programa 2007 tinha preço de exercício estipulado em R \$ 21,00 por Unit e o Programa 2008 em R\$ 20,00 por Unit. As Units da ALL compõem-se de certificados de depósito de ações representando, cada certificado, 1 (uma) ação ordinária (ON) e 4 (quatro) ações preferenciais (PN) de emissão da empresa. No período 2007/2008 as Units superaram a cotação de $\mathrm{R} \$ 25,00$, mas com a depreciação experimentada com a Crise Econômica criou-se uma situação que faria com que os Beneficiários não tivessem interesse em exercer seus direitos, já que o exercício se traduziria em prejuízo no momento em que as ações fossem negociadas no mercado. A empresa então procedeu ao cancelamento das opções dos Programas 2007 e 2008, substituindo-as por opções do programa 2009 - com preço de exercício mais baixo, na razão de 9 para 5. O Programa 2009 foi lançado com o preço de exercício de $\mathrm{R} \$ 11,00$ por Unit (o preço de mercado na data era de $\mathrm{R} \$ 12,35$ ). A deliberação do Comitê está documentada na Ata de 03 de agosto de 2009, conforme abaixo:

21) Em 10 de setembro de 2010 foi instituído o Programa de Opção de Compra de Ações 2010, o qual prevê preço de exercício de R\$ 0,01 por ação (o preço médio de mercado nessa data era de $\mathrm{R} \$ 16,50)$. O Programa 2010 condiciona o direito à outorga das opções a parâmetros de desempenho global da empresa (meta para o EBIDTA) e a parâmetros de desempenho individual dos Beneficiários (pontuação igual ou superior a 80 pontos na média dos exercícios sociais de 2010, 2011 e 2012, de acordo com o Sistema Integrado de Gestão). As outorgas poderão ser exercidas a partir do cumprimento das condições referidas no Programa, conforme abaixo:

22) A Deliberação CVM no 562, de 17 de dezembro de 2008, da Comissão de Valores Mobiliários aprovou o Pronunciamento Técnico CPC 10 do Comitê de Pronunciamentos Contábeis, que trata de Pagamento Baseado em Ações, o qual descreve em sua Visão Geral:

\section{COMITÊ DE PRONUNCIAMENTOS CONTÁBEIS PRONUNCIAMENTO TÉCNICO CPC 10 (R1)}

Pagamento Baseado em Ações Correlação às Normas Internacionais de Contabilidade - IFRS 2 (IASB - BV 2010) 12. Via de regra, ações, opções de ações ou outros instrumentos patrimoniais são concedidos aos empregados como 
parte da remuneração destes, adicionalmente ao salário e outros benefícios concedidos. Normalmente não é possível mensurar de forma direta cada componente específico do pacote de remuneração dos empregados, bem como não é possível mensurar o valor justo do pacote como um todo. Portanto, é necessário mensurar o valor justo dos instrumentos patrimoniais outorgados. Além disso, ações e opções de ações são concedidas como parte de um acordo de pagamento de bônus ao invés de o serem como parte da remuneração básica dos empregados, ou seja, trata-se de incentivo para permanecerem empregados na entidade ou de recompensa por seus esforços na melhoria do desempenho da entidade. Ao beneficiar empregados com a concessão de ações ou opções de ações adicionalmente a outras formas de remuneração, a entidade visa a obter benefícios adicionais. Em função da dificuldade de mensuração direta do valor justo dos serviços recebidos, a entidade deve mensurálos de forma indireta, ou seja, deve tomar o o valor justo dos instrumentos patrimoniais outorgados como o valor justo dos serviços recebidos (grifo nosso).

23) Em observância às disposições do Pronunciamento Técnica CPC 10, a empresa passou a reconhecer as despesas registradas com serviços recebidos de empregados nos períodos, decorrentes de transações de pagamento baseadas em ações, somando R\$ 22.247.000,00 em 31 de dezembro de 2010 e R\$ 20.290.000,00 em 31 de dezembro de 2009, conforme Notas Explicativas abaixo:

24) As Notas Explicativas da Administração às Demonstrações Financeiras para o exercício findo em 31/12/2010 esclarecem que as contribuições de cada Beneficiário são contabilizadas como "Adiantamento para Futuro Aumento de Capital” a partir de controles individuais.

25) A empresa apresentou o "Controle Histórico de Exercícios de Opções e Entrega de Ações aos Beneficiários” (fls. 680/697). Consiste em contacorrente por Beneficiário onde são registradas as suas contribuições. Existem duas formas de contribuição: por depósito em contacorrente da empresa ou retenção em folha de pagamento. A retenção em folha de pagamento ocorre principalmente no mês de fevereiro, quando são creditados os valores referentes ao Programa de Remuneração Variável mantido pela empresa. Na análise da cláusula sexta dos "Contratos de Oferta à Subscrição ou Compra a Termo de Ações e Outros Pactos" verificamos a possibilidade de os Beneficiários, a partir da integralização de $30 \%$ das suas obrigações, requererem a emissão das ações, aliená-las por corretora designada pela empresa. Nesta operação a corretora repassará os $70 \%$ restantes das obrigações do Beneficiário diretamente para a empresa, creditando o saldo remanescente ao Beneficiário. O procedimento é detalhado no item 6.2.

26) Conforme observado nos itens precedentes, concluímos:

a) O "Plano de Opção de Compra de Ações" tem natureza remuneratória, destinando-se a criar um atrativo ao Beneficiário e a mantê-lo na empresa pela promessa de ganhos futuros;

b) O lançamento de Programas tem caráter de habitualidade, com periodicidade anual, à exceção de 2002 e 2004;

c) O Comitê afasta o eventual risco das operações por meio de empréstimos aos Beneficiários, de modo que todos possam aderir ao Plano e intervêm quando as condições de mercado tornam o exercício das opções desvantajosas aos Beneficiários, conforme demonstrado por ocasião da substituição das opções dos Programas 2007 e 2008 pelo Programa 2009;

d) O Comitê possibilita aos Beneficiários a alienação de suas opções não integralizadas, retendo o valor referente ao pagamento do exercício. A alienação 
é feita por corretora designada pela empresa. Combinando a possibilidade de contrair empréstimo para o pagamento da parcela inicial de 10\% para adesão ao Programa e a alienação das ações em operação simultânea à quitação do valor do exercício, o Beneficiário evita o próprio desembolso e afasta qualquer risco na operação, já que tem condições de escolher a melhor ocasião para a venda, em momento anterior ao da integralização de suas opções;

e) O Comitê possui poderes para definir os Beneficiários e para outorgar opções de acordo com as suas atribuições e como o desempenho individual de cada um;

f) A empresa ofertou Programa 2010 por valor vil (R\$ 0,01 por ação), dirimindo qualquer dúvida quanto ao caráter remuneratório do mesmo;

g) O Programa 2010 explicita condições para o exercício do Programa, as quais são metas de natureza coletiva (EBITDA da empresa) e de natureza individual (avaliação por meio de Sistema Gerencial), corroborando a contraprestação. Apesar de o período de carência para o exercício das opções estender-se até 31/12/2012, o Programa 2010 expõe de maneira cristalina os objetivos do "Plano de Opção de Compra de Ações” da empresa.

Novamente nos deparamos com uma decisão desfavorável para o contribuinte. Não obstante, o Conselheiro presidente Elias Sampaio Freire destacou que a SOP em sua concepção original, possui caráter mercantil, afastando assim a incidência das contribuições previdenciárias.

À esse respeito segue trecho de seu voto, que além de reconhecer a natureza mercantil das operações envolvendo a SOP, ainda aduz é responsabilidade da fiscalização comprovar eventual desvirtuamento do Plano estipulado por meio das SOPs:

"Em sua concepção original o stock option é mera expectativa de direito do trabalhador (seja empregado, autônomo ou administrador), consistindo em um regime de opção de compra de ações por preço prefixado, concedida pela empresa aos contribuintes individuais ou mesmo empregados, garantindo-lhe a possibilidade de participação no crescimento do empreendimento (na medida que o sucesso da empresa implica, valorização das ações no mercado), não tendo inicialmente caráter salarial, sendo apenas um incentivo ao trabalhador após um período predeterminado ao longo do curso do contrato de trabalho.

(...)

Partindo do pressuposto de que os planos de opções de compra de ações (Stock Options) possuem natureza mercantil. Cabe a autoridade fiscal o ônus de demonstrar e comprovar que houve desvirtuamento dos referidos planos, a ponto de que venham a ser desnaturados como decorrentes de uma operação mercantil e caracterizados como remuneração indireta.

Não comungo do entendimento de que a ausência de demonstração do desvirtuamento dos planos de opções de compra de ações (Stock Options) trate-se de mero vício formal, posto que caso a fiscalização não demonstre o efetivo desvirtuamento há de ser mantida a natureza mercantil dos referidos planos, que não se sujeitam à incidência de contribuições previdenciárias, o que acarreta a improcedência do lançamento.” 
Seguindo esse entendimento de natureza mercantil do Plano de Stock Options, a Conselheira Relatora Elaine Cristina Monteiro e Silva Vieira se posiciona no sentido de que a SOP é uma mera expectativa de direito, vejamos:

“Ou seja, em termo conceituais, no entender desta relatora, a stock option é mera expectativa de direito do trabalhador (seja empregado, autônomo ou administrador), consistindo em um regime opção de compra de ações por preço prefixado, concedida pela empresa aos contribuintes individuais ou mesmo empregados, garantindo-lhe a possibilidade da participação no crescimento do empreendimento (na medida que o sucesso da empresa implica, valorização das ações no mercado), não tendo caráter salarial, sendo apenas um incentivo ao trabalhador após um período predeterminado ao longo do curso da prestação de serviços (seja no contrato de trabalho, seja em contrato autônomo).

No mesmo sentido, tem-se encaminhado os renomados doutrinadores trabalhistas brasileiros, dentre eles cite-se a professora Alice Monteiro de Barros (in Curso de Direito do Trabalho, 6.a ed., São Paulo: LTR, 2010, p. 783):

"As stock option constituem um regime de compra ou de subscrição de ações $e$ foram introduzidas na França em 1970, cujas novas regras encontram-se na Lei n. 420, de 2001. Não se identificam com a poupança salarial. O regime das stock option permite que os empregados comprem ações da empresa em um determinado período e por preço ajustado previamente.

É no mesmo sentido, que discordo de um dos argumentos trazidos pelo auditor, citando uma reclamatória trabalhista, a qual encaminhou o magistrado o julgamento no sentido de que toda a forma de stock options, tende a remunerar, premiar o trabalhador pela prestação de serviços.

Embora, a concessão da opção por ações tenha decorrido da prestação de serviços, trata-se, em regra, de típico contrato mercantil, envolvendo riscos, podendo o trabalhador, auferir lucros ou não com a outorga de ações, tudo a depender da situação do mercado."'(grifou-se)

Ocorre que, no presente caso, apesar do reconhecimento do caráter mercantil das transações envolvendo a compra de ações, os Conselheiros julgadores entenderam ter havido distorção da natureza mercantil da SOP, uma vez que a empresa teria interferido diretamente no "Plano de Opção de Compra de Ações”:

“Ocorrendo uma distorção das Stock Options em sua concepção inicial, ou seja, a mera operação mercantil, seja através da concessão de empréstimos, possibilidade de venda antecipada, mudança de planos, a correlação com o desempenho no trabalho, retenção de talentos, é claro que a intenção de anular (ou minimizar) o risco atribuído ao negócio em si configura uma forma indireta de remuneração". 
Esta conclusão é decorrente da presença em alguns casos, da concessão de empréstimos realizados pela companhia aos seus executivos para que estes pudessem aderir ao plano por meio do pagamento de $10 \%$ dos lotes das ações ofertadas. A empresa também em demais oportunidades, devido à crise mundial, cancelou o plano anterior, disponibilizando assim outro plano com valor menor das ações para exercício do direito.

O Plano disponibilizado pela companhia, ainda tinha mais um peculiaridade, qual seja a venda antecipada das ações adquiridas, sem a devida integralização por parte empregado.

Ademias, os Planos de Opções de Ações em vigor a partir do ano de 2010 estavam diretamente relacionados ao desempenho individual de cada empregado. Como argumento trazido pelo fisco, ainda foi levando em consideração o valor irrisório atribuído as ações, prefixados em R \$ 0,01 por ação, o que ao seu ver estaria mascarando a remuneração, acarretando em simulação tributária.

Em outras palavras, a natureza mercantil foi afastada no caso concreto devido a três principais fatores, quais sejam: (i) a inexistência de risco por parte do empregado; (ii) objetivo principal ser a retenção de talentos; e (iii) correlação entre o desempenho individual de cada empregado e a possibilidade de sua elegibilidade ao plano.

Sobre esses três pilares que permitiram a descaracterização da natureza mercantil do plano adotado pela companhia, a Conselheira Relatora Elaine Cristina Monteiro e Silva Vieira, expõe:

"Vislumbro pontos básicos a serem observados que demonstram os motivos para vincular a compra de ações, a uma espécie de remuneração indireta:

- Prestação do serviços, o que restou demostrado inclusive com a vinculação da opção pela compra ao desempenho global da empresa e parâmetros de desempenho individual, mantendo os ditos "talentos" dentro do foco de interesse da empresa.

- Ideia de fidelização do prestador do serviços, com a indicação de prazo para o exercício do direito a compra, ou seja, era necessário estar com um vínculo em determinada data, para poder exercer o direito de compra, relacionando diretamente a opção como contrapartida pela prestação de serviços. 
Ausência de risco para o trabalhador, o que afasta a concepção original de contrato mercantil, na medida que a empresa estabeleceu valores abaixo do valor de mercado, concedeu empréstimos, facilitando a opção, seja pela ausência de desembolso imediato, seja pela possibilidade de pagamento com ganhos incertos, ou mesmo pelo ganho com a venda antecipada de ações (digase até mesmo cujo direito à totalidade das ações ainda não havia se integralizado), cancelou planos que pela crise no mercado financeiros não ofertaria vantagem aos trabalhadores, bem como possibilidade de venda, sem nem mesmo ter integralizado a totalidade do direito a ação. “

Já no tocante à posterior alteração do plano, é certo que a intenção da companhia foi contribuir para que os empregador auferissem ganho com a operação, razão pela qual há de se concordar com o entendimento exarado pelo fisco:

"Não merece guarida o argumento de que a troca de plano tem por objetivo proteger patrimônio da entidade. No próprio recurso o recorrente descreve que o cancelamento dos planos de 2007 e 2008, também almejou a preservação da sua finalidade: manter talentos, por intermédio da adesão a um plano de opção de compra de ações que pudesse proporcionar uma mínima expectativa de ganhos futuros aos trabalhadores. Ora, o risco do Stock Options é justamente esse, enfrentar o trabalhador, a incerteza de possíveis perdas. Não vejo, que 0 recorrente tenha se desincumbido de afastar as alegações fiscais quanto a esse ponto, razão porque mantenho o lançamento.” (grigou-se)

Fazendo um análise sobre os empréstimos realizados pela empresa aos empregados para que estes pudessem aderir ao plano, o fisco também entendeu que tal previsão eliminaria o risco mercantil do negócio.

Todavia, quanto a este ponto há de se discordar, uma vez que se os empréstimos seguiram as regras do mercado, por si só não possuem o condão de afastar o risco da operação. Em consonância com tal entendimento, a Conselheira Carolina Wanderley Landim em sua “Declaração de Voto”, bem asseverou:

"Quanto à concessão de empréstimo para pagamento da contribuição para aquisição do lote inicial correspondente a $10 \%$ das ações ofertadas no programa do ano de 2006, também entendo que não há, no caso, afastamento do risco inerente à compra de ações com tal faculdade, como já muito bem fundamentado no voto proferido pelo Ilustre conselheiro Igor Araújo Soares.

Não se trata de doação, mas de efetivo empréstimo, sujeito, como tal, a remuneração correspondente a $100 \%$ da taxa média referencial dos depósitos interfinanceiros apurada pela CETIP, conforme cláusula 7 da minuta do contrato de empréstimo acostada às fls. 136 dos autos.

O beneficiário, portanto, assumia um passivo perante a Companhia, sujeito à incidência de juros, para compra inicial de suas ações, ações estas que, dois anos 
após, poderiam valer muito menos do que o valor pago para a sua aquisição. Não há, portanto, qualquer afastamento de risco com a concessão do empréstimo comentado. Ao contrário, a assunção de dívida para aquisição de ações implica a assunção de um risco ainda maior por parte do beneficiário do programa, já que o investimento no mercado de ações é por natureza arriscado, sujeito às desvalorizações e perdas que lhe são inerentes. O beneficiário pode, assim, sofrer perdas em decorrência da desvalorização das suas ações e, ainda assim, assumir um passivo decorrente do empréstimo tomado, o qual inclusive aumentará de valor com o tempo.”

Com relação ao preço vil das ações concedidas ( $\mathrm{R} \$$ 0,01), devemos lembrar que o valor do desconto não pode ser tão significativo que consiga eliminar o risco da operação, tendo em vista que retiraria o caráter oneroso da concessão do plano.

Quanto ao momento de ocorrência do fato gerador, das contribuições previdenciárias no caso de SOP, a Conselheira Relatora seguir o entendimento inicial da autuação, que considerou o fato gerador ocorrido no momento da outorga das ações ao empregado, conforma trecho abaixo:

"Muito discutiu o recorrente argumentando que não houve pagamento ou mesmo ganho, e portanto, a verba não poderia constituir salário de contribuição, sendo indevida o lançamento em relação a este período, o que não venho a concordar.

Argumenta que tão somente se o beneficiário vendesse a ação, poderia se vislumbrar alguma espécie de ganho, e mesmo assim, caso ocorresse, seria uma relação desvinculada da autuada, não havendo como estabelecer o liame jurídico, capaz de determinar sua sujeição passiva pelos créditos ora lançados.

Acho que o entendimento levado a efeito pela autoridade fiscal, encontra-se acertado. Ora, em que momento houve o "ganho", ou conforme descrito anteriormente a remuneração indireta do trabalhador?

Acredito que, no momento em que houve o direito de opção (com a efetiva outorga) pela ações ocorreu, sim, o fato gerador, mesmo que não tenha havido a efetiva venda a terceiro, pois naquela oportunidade o mesmo integralizou a efetiva compra das ações sobre o preço de exercício, valor inferior aquela oportunidade ao preço de mercado, representando um ganho direto do trabalhador. Conforme demonstrado acima, houve o desvirtuamento do stock options em sua natureza inicial, qual seja, mera operação mercantil, razão pela qual procedeu o auditor ao lançamento do ganho real, (diferença entre o preço de exercício e o preço de mercado no momento da opção pela compra de ações.). Não tivesse ocorrido ditos fatos não se discutiria a ocorrência do fato gerador, posto que não restaria caracterizada a remuneração indireta.

Afasto, dessa forma, o argumento de eventual diferença entre o valor da ação no pregão da bolsa e o valor da ação pago pelo beneficiário do Plano de Opção de Compra de Ações da Recorrente seria irrelevante e imprestável para a cobrança do tributo. Pelo contrário, ao fornecer o benefício ao trabalhador, inclusive com a possibilidade de venda, sem nem mesmo ter completado o prazo de carência 
determinado, ofertou a recorrente ao trabalhador um ganho indireto, cuja definição da base de cálculo deu-se sobre o ganho auferido pelo beneficiário.

Assim, como já demasiadamente descrito, realmente entendo que o ganho inicial pela outorga de ações não constitui salário de contribuição, vez tratar-se de operação mercantil, contudo, na forma como pago, representando um ganho na forma de utilidade (como veremos adiante), correto o lançamento realizado.

Ademais, também afasto o argumento de que o fato gerador (se existisse) só se daria no momento da venda a terceiros. O momento da ocorrência do fato gerador, deu-se com a concretização da opção, auferindo um ganho indireto. (o direito de compra). Não podemos dizer que se dará apenas com a venda, pois poderemos nos deparar com situações em que o empregado nunca realizasse essa venda.”

Por fim, em relação à necessidade de integralização parcial quando da adesão ao Plano, novamente bem explicitou a Conselheira Carolina Wanderley Landim, quando entende que a proibição da venda de ações durante um longo período de vesting (carência) reforça a existência de risco para o negócio, forçando ainda mais a evidência da natureza mercantil da SOP:

\begin{abstract}
“Avaliando a cláusula contratual acima transcrita, entendo que ela não afasta o risco assumido pelo beneficiário ao optar pelo programa de compra de ações, já que tal faculdade não podia ser exercida no momento da opção pelo programa quando, teoricamente, a ação adquirida possuía valor de mercado ligeiramente superior ao de compra.
\end{abstract}

Isto porque, havia nos programas dos anos de 2005, 2006 e 2007 cláusula prevendo a proibição de alienação das ações por dois anos contados da data da adesão, sendo que, dois anos após, não é possível prever se as ações originalmente ofertadas por determinado valor terão preço superior ou inferior no mercado. Esse risco, por certo, não é afastado com a possibilidade de integralização de $30 \%$, ao invés de $100 \%$ do valor de contribuição das ações.

Não se pode, portanto, tratar tal faculdade como hábil a caracterizar o plano de ações como remuneração, já que não é possível saber se, dois anos após a adesão ao programa, as ações terão valor superior ou inferior ao preço de exercício estipulado. Tal certeza só poderia existir se a Recorrente tivesse ofertados suas ações nesses anos a preço vil, fato que não foi demonstrado em momento algum pela fiscalização (apenas quanto ao ano de 2010).

Uma cláusula dessa natureza poderia ser contestado no contexto de planos que permitem imediatamente após a opção a venda das ações, ações estas que são ofertadas por valor consideravelmente inferior ao de mercado, na data da concessão (não do exercício). Nesses casos, pode ficar demonstrado que o plano tinha por objetivo propiciar um ganho certo e imediato ao beneficiário, o que não me parece ser o caso ora analisado.

O fato de ser estabelecido contratualmente que a venda será feita por corretora designada pela Recorrente também não desnatura o plano, já que tal previsão visa afastar o risco de a Recorrente (e não do beneficiário) não receber a parte do 
produto da venda das ações que lhe cabe, o que aconteceria caso o beneficiário recebesse o produto da venda e descumprisse com a sua obrigação de pagar os $70 \%$ do preço restantes. Na verdade, a cláusula aqui comentada acaba por comprovar a onerosidade do contrato, já que garante que o preço integral da ação será pago, sem o risco de o beneficiário não cumprir com a sua obrigação contratual.

A possibilidade de integralização de $30 \%$ do preço das ações para seu recebimento e venda não provoca, assim, afastamento de risco por parte do beneficiário.”

Diante de todo o exposto, é possível verificar que a decisão foi desfavorável ao contribuinte, tendo sido os valores recebidos à título de SOPs considerados como remuneração. Porém vale destacar que novamente estamos diante de uma decisão não unânime, o que mostra que ainda há muita discussão a ser enfrentada.

É importante ainda ressaltar que apesar de ter sido uma decisão desfavorável, é de suma relevância, uma vez que reconheceu o caráter mercantil da SOP.

Por fim, apenas para fins informativos, a discussão ainda não encontra-se encerrada na esfera administrativa, pois ainda aguarda-se o julgamento dos Embargos de Declaração opostos pela empresa (All América Latina).

\subsection{Jurisprudência na esfera judicial e as tendências da jurisprudência atual}

À título de recordação, foi na esfera judicial trabalhista onde inicialmente em 2008 formou-se a primeira jurisprudência brasileira sobre qual a natureza jurídica dos Planos baseados em Ações. Com efeito, o TST firmou o entendimento de que "a concessão de direitos atrelados a ações não possuía caráter remuneratório."

Pelo contrário, na verdade os ganhos auferidos pelo empregado seriam uma forma indireta de participação nos lucros, sem qualquer garantia de rentabilidade, nem vínculo contra prestativo com a forca de trabalho do empregado. 
Isto porque, em que pese a verba - decorrente da bonificação acionária - seja concedida anualmente, no entanto, não se observa uma gratificação stricto sensu, pois o seu recebimento estará condicionado ao investimento na compra de ações, notadamente vulneráveis aos riscos do instável mercado financeiro.

Neste sentido, a participação acionária do empregado não caracterizaria necessariamente uma contraprestação aos seus serviços, porquanto não há qualquer caráter retributivo do seu labor à empresa.

Ainda que a possibilidade do negócio decorra do contrato de trabalho, porém, caso haja algum benefício financeiro do empregado, este não será revestido de natureza salarial, pois será em consequência da eventual valorização e, posterior, venda das ações pertencentes ao seu patrimônio particular.

Ressaltou-se que um potencial ganho de capital do empregado dependerá das flutuações dessas ações na Bolsa de Valores, ou seja, fato completamente alheio à prestação de serviços fornecidos à empresa.

Contudo, segundo o entendimento majoritário da Justiça do Trabalho, a concessão de SOPs deveria ser feita de forma onerosa para que não houvesse natureza salarial, ou seja, a onerosidade tornou-se pressuposto para a caracterização da verba como não remuneratória.

Somente após o início das fiscalizações e autuações da Receita Federal, os contribuintes ajuizaram medidas judiciais que, em meados de 2012, finalmente ensejaram precedentes no âmbito da Justiça Federal.

Ato contínuo, a Seção Judiciária de São Paulo julgou o caso Skanska Brasil Ltda. ${ }^{22}$, empresa que pleiteou a inexistência de relação jurídicotributária que a obrigasse ao recolhimento de contribuições previdenciárias sobre a concessão de direitos sobre ações de sua controlada estrangeira.

Em síntese, a empresa arguiu adesão ao Programa de Opções de Compra de Ações (SEOPs 1 e 2), segundo o qual os empregados poderiam

\footnotetext{
${ }^{22}$ Processo n. 021090-58.2012.4.03.6100 - 10a Vara Federal da Subseção Judiciária de São Paulo. Disponibilizado no Diário Eletrônico de sentença em 29.10.2013, p. 74-94.
} 
exercer a opção de compra acionária mediante o desconto de um percentual mensal em sua folha de salários.

Neste ensejo, a sentença julgou procedente o pedido da empresa e reconheceu o caráter não remuneratório do referido Programa, ainda que neste caso os benefícios fossem relacionados à performance do empregado - o que retira o perfil exclusivamente mercantil do contrato, mas não o caracteriza como retribuição à força de trabalho prestada pelo empregado.

Ademais, apesar das transações gratuitas (cashless), a sentença entendeu que o risco de mercado não restou anulado, pois seria possível que o empregado não obtivesse lucro, ou até mesmo tivesse prejuízo com uma eventual desvalorização das ações - possibilidade incompatível com a ideia de retribuição ao trabalho.

Por outro lado, no caso do Grupo GVT ${ }^{23}$ o Tribunal Regional Federal da $4^{\mathrm{a}}$ Região entendeu que o simples fato de existirem condições prévias para a concessão de SOPs, já comprovaria a natureza salarial decorrente da contraprestação do serviço pelo empregado.

Em sua análise, o magistrado entendeu que o Stock Option possui evidente relação com o contrato de trabalho e a prestação do serviço, porquanto se exige período de carência na manutenção da prestação dos serviços, para que se possa exercer o direito de compra das ações.

Já quanto a inexistência de risco mercantil, foi rechaçada a tese da área própria do mercado de ações, pois o magistrado entendeu não parecer haver "efetivo e concreto risco de o empregado ou contribuinte individual ter prejuízo com sua opção de compra."

Isto porque, enquanto comercializada em valor abaixo do prefixado, o investidor não optaria pela compra da ação, pois aguardaria dentro do período por uma eventual valorização. Caso houvesse álea, esta surgiria somente após a aquisição da ação, até uma futura venda.

\footnotetext{
${ }^{23}$ Processo n. 5058161-61.2013.404.7000 - 6ª Vara Federal da Subseção Judiciária de Curitiba. Disponibilização no Diário Eletrônico de sentença em 12.12.2013.
} 
Portanto, ao final a problemática acerca da concessão de SOPs restou pacificada apenas na jurisprudência trabalhista, que reconheceu a natureza não salarial dos Planos baseados em Ações, uma vez preenchidos certos requisitos, como a onerosidade).

Por outro lado, ainda não há um posicionamento sedimentado sobre a não incidência de contribuições previdenciárias sobre pagamentos decorrentes de Planos baseados em Ações, justamente pelo fato da matéria ser recente no Judiciário. Não obstante, considerando a ótica constitucional, não levará muito tempo para essa questão ser ventilada no Superior Tribunal Federal. 


\section{CAPÍTULO 5. REFLEXOS NA TRIBUTAÇÃO DO IMPOSTO DE RENDA DA PESSOA FÍSICA}

\subsection{A tributação da pessoa física do beneficiário}

Passaremos agora a analisar talvez um dos pontos mais difíceis a ser enfrentado no tocante aos Planos de Ações, que é justamente identificar o fato gerador do imposto de renda da pessoa física (IRPF) , bem como a base de cálculo e alíquota aplicáveis.

Conforme disposto no artigo $142^{24}$ do Código Tributário Nacional, a autoridade fiscal é a responsável não somente pela identificação do fato gerador, mas também determinar a matéria tributária, definir a alíquota aplicável, e ainda, calcular o imposto devido. Ocorre que, para fins do Imposto de Renda da Pessoa Física o lançamento é realizado mediante homologação, de acordo com o que estabelece o artigo $150^{25}$ e seus parágrafos, também do Código Tributário Nacional.

Em se tratando de imposto cujo lançamento se dá por homologação, cabe à pessoa física do beneficiário identificar a ocorrência do fato gerador,

\footnotetext{
${ }^{24}$ Art. 142. Compete privativamente à autoridade administrativa constituir o crédito tributário pelo lançamento, assim entendido o procedimento administrativo tendente a verificar a ocorrência do fato gerador da obrigação correspondente, determinar a matéria tributável, calcular o montante do tributo devido, identificar o sujeito passivo e, sendo caso, propor a aplicação da penalidade cabível.

Parágrafo único. A atividade administrativa de lançamento é vinculada e obrigatória, sob pena de responsabilidade funcional.

${ }^{25}$ Art. 150. O lançamento por homologação, que ocorre quanto aos tributos cuja legislação atribua ao sujeito passivo o dever de antecipar o pagamento sem prévio exame da autoridade administrativa, opera-se pelo ato em que a referida autoridade, tomando conhecimento da atividade assim exercida pelo obrigado, expressamente a homologa.

$\S 1^{\circ} \mathrm{O}$ pagamento antecipado pelo obrigado nos termos deste artigo extingue o crédito, sob condição resolutória da ulterior homologação ao lançamento.

$\S 2^{\circ}$ Não influem sobre a obrigação tributária quaisquer atos anteriores à homologação, praticados pelo sujeito passivo ou por terceiro, visando à extinção total ou parcial do crédito.

$\S 3^{\circ}$ Os atos a que se refere o parágrafo anterior serão, porém, considerados na apuração do saldo porventura devido e, sendo o caso, na imposição de penalidade, ou sua graduação.

$\S 4^{\circ}$ Se a lei não fixar prazo a homologação, será ele de cinco anos, a contar da ocorrência do fato gerador; expirado esse prazo sem que a Fazenda Pública se tenha pronunciado, considera-se homologado o lançamento e definitivamente extinto o crédito, salvo se comprovada a ocorrência de dolo, fraude ou simulação.
} 
determinar a matéria tributável verificar a alíquota aplicável, e por fim, calcular e pagar o tributo devido.

O fisco nesses casos, assume apenas o papel de homologador do crédito tributário decorrente do Plano de Ações. Sendo assim, apenas após verificar as informações oferecidas pela pessoa física do beneficiário, e estando em desacordo com os critérios por ela utilizados, é que caberá às autoridades administrativas constituir o lançamento tributário.

Restando claras estas primeiras considerações, passamos então analisar qual seria o fato econômico a ser atingido pela tributação do imposto de renda da pessoa física quando estamos diante de um cenário que envolve Planos de Ações.

O direito constitucional brasileiro dispõe que é de competência da União a instituição de imposto sobre a renda e proventos de qualquer natureza. Além disso, o referido imposto seguirá os princípios tributário da generalidade, da universalidade e da progressividade, nos moldes do artigo 153, III, §2º I $^{26}$ da Constituição Federal.

O princípio da generalidade pode ser entendido como aquele que abarca qualquer pessoa que aufira renda e proventos de qualquer natureza, devendo submeter-se à tributação. Já o princípio da universalidade compreende o entendimento de que a tributação da pessoa física deve atingir toda renda e proventos de qualquer natureza seja identificada no Brasil ou no exterior. E, por fim, o princípio da progressividade pressupõe a aplicação de alíquotas diferenciadas para cada faixa de renda a ser oferecida à tributação.

\footnotetext{
${ }^{26}$ Art. 153. Compete à União instituir impostos sobre:

(...)

III - renda e proventos de qualquer natureza;

(...)

$\S 2^{\circ} \mathrm{O}$ imposto previsto no inciso III:

I - será informado pelos critérios da generalidade, da universalidade e da progressividade, na forma da lei;
} 
A legislação tributária delimita a questão acerca da tributação pelo imposto de renda no artigo $43^{27}$ do Código Tributário Nacional, determinando que seu fato gerador é a disponibilidade econômica ou jurídica da renda e dos proventos de qualquer natureza.

Vejamos os imprescindíveis ensinamentos de Rubens Gomes de Souza ${ }^{28}$ no que diz respeito à dicotomia entre o que vem a ser disponibilidade econômica e jurídica:

“(...) disponibilidade econômica corresponde a rendimento (ou provento) realizado, isto é, dinheiro em caixa. E disponibilidade jurídica corresponde a rendimento (ou provento) adquirido, isto é, ao qual o beneficiário tem título jurídico que lhe permite obter a respectiva realização em dinheiro (p. ex., os juros ou dividendos creditados). Assim, a disponibilidade econômica inclui a jurídica; a recíproca não é verdadeira, mas pelo art. 43, qualquer das duas hipóteses basta para configurar o fato gerador do imposto”.

Seguindo esse entendimento, temos que a disponibilidade econômica significa então, o ingresso do dinheiro automaticamente no patrimônio da pessoa física ou jurídica, enquanto na disponibilidade jurídica, o ingresso do título do jurídico, para que depois seja convertido em dinheiro.

Atualmente, a doutrina firmou o entendimento de que para que haja a ocorrência do fato gerador do imposto de renda da pessoa física, não basta haver somente a disponibilidade da renda e dos proventos de qualquer natureza, mas sim a efetiva disponibilidade econômica, que importe na chamada "renda acréscimo" caracterizando assim, o acréscimo patrimonial da pessoa física.

Inclusive, a referida tese já foi reproduzida quando do julgamento do acórdão RE 614.406 realizado pelo Plenário do Supremo Tribunal Federal,

\footnotetext{
${ }^{27}$ Art. 43. O imposto, de competência da União, sobre a renda e proventos de qualquer natureza tem como fato gerador a aquisição da disponibilidade econômica ou jurídica:

I - de renda, assim entendido o produto do capital, do trabalho ou da combinação de ambos;

II - de proventos de qualquer natureza, assim entendidos os acréscimos patrimoniais não compreendidos no inciso anterior.

§ 1o A incidência do imposto independe da denominação da receita ou do rendimento, da localização, condição jurídica ou nacionalidade da fonte, da origem e da forma de percepção.

$\S 2 \underline{o}$ Na hipótese de receita ou de rendimento oriundos do exterior, a lei estabelecerá as condições e o momento em que se dará sua disponibilidade, para fins de incidência do imposto referido neste artigo.

${ }^{28}$ SOUZA, Rubens Gomes. Pareceres I - Imposto de Renda. Edição Póstuma. São Paulo: Resenha Tributária, 1975. p. 70.
} 
em 23.10.2014, sob a relataria da Ministra Rosa Weber, conforme trecho abaixo:

“É importante destacar que o imposto de renda da pessoa física, por opção do legislador, tem na percepção dos rendimentos seu próprio aspecto material. Não surge obrigação sem que haja a efetiva disponibilidade econômica da renda.

(...)

Tributos de cunho pessoal, como o imposto de renda, admitem a concretização direta de tal princípio. De um lado, apura-se a renda tributável permitindo-se a dedução de despesas consideradas necessárias ou fundamentais; de outro, graduase a tributação conforme as faixas de rendimentos.

Na apuração da renda reveladora de capacidade contributiva, cabe dizer que é o regime de caixa que melhor afere a possibilidade de contribuir.

Isso porque implica exigir o pagamento do imposto à luz dos rendimentos efetivamente percebidos pela pessoa física, independentemente de quando tenha surgido o direito a eles. Só é tributado o que efetivamente ingressa para o contribuinte e que está na sua disponibilidade econômica, podendo ser utilizado para o pagamento do tributo.

A percepção efetiva de rendimentos é posta pelo legislador como aspecto material da norma tributária impositiva em questão porque constitui fato revelador de riqueza que se enquadra entre as bases econômicas cuja tributação é constitucionalmente atribuída à União. Tal revelação de riqueza denota, sem dúvida, capacidade contributiva contemporânea à sua ocorrência.

Quando auferida a renda, cabe ao seu titular cumprir seu dever fundamental de pagar tributo, recolhendo o imposto de renda que, nos termos da tabela vigente, seja então devido.”

Ainda, sob a mesma ótica, vale destacar outro julgado, o acórdão RE 611.586, também do Plenário do STF, em 10.04.2013, que deixa claro o posicionamento de que o fato gerador do imposto de renda da pessoa física

é a disponibilidade econômica, dimensionada pelo regime de caixa e tributável na medida do seu efetivo recebimento, in verbis:

“Observo, em primeiro lugar, que os conceitos disponibilidade econômica e jurídica, utilizados pelo direito tributário, tem sentidos distintos quando aplicados às pessoas físicas e às pessoas jurídicas.

(1) Regime de Caixa e Regime de Competência.

A base de tal distinção - ou diferença - está no regime a que cada uma delas física ou jurídica - estão submetidas.

Para as pessoas físicas impera o Regime de Caixa.

Já, para as pessoas jurídicas, o Regime de Competência.

No Regime de Caixa, exige-se o registro de receitas e despesas quando efetivamente recebidas ou pagas. Somente quando recebido o valor do crédito ou quando pago o valor do débito tem-se a alteração, para mais ou para menos, no patrimônio da pessoa física.

A só existência do direito subjetivo ou da obrigação, exigíveis, não altera, para fins tributários, a situação patrimonial da pessoa física." 
Não obstante, a previsão contida no Código Tributário Nacional, e em consonância, a jurisprudência do Pleno do STF, de que o fato gerador do imposto de renda da pessoa física é a disponibilidade econômica da renda medida através do regime de caixa, quando houver efetivo acréscimo patrimonial, os dispositivos da Lei Ordinária e aqueles que a regulamentam, não são tão claros, gerando muita vezes a possibilidade pela aplicação do entendimento de que de que também pode afigurar como fato gerador do imposto de renda da pessoa física, a disponibilidade jurídica da renda.

Como principal exemplo disso, temos o artigo 55, IV do Regulamento do Imposto de Renda de 1999 (RIR/99):

“São também tributáveis (Lei 4.506, de 1964, art. 26 da Lei 7.713, de 1988, art. 3. ${ }^{\circ}$, § $4^{\circ}$, e Lei 9.430 , de 1996, arts. 24 , § $2 .^{\circ}$, IV e 70, § 3. ${ }^{a}$, I):

(...)

IV - os rendimentos recebidos na forma de bens ou direitos avaliados em dinheiro, pelo valor que tiverem na data da percepção”.

O dispositivo legal supracitado possui vícios irreparáveis, pois como já foi dito anteriormente, o fato gerador do imposto de renda da pessoa física é a disponibilidade econômica da renda, que significa "ter dinheiro em caixa”. Sendo assim, se a pessoa física recebe bens ou títulos no lugar de dinheiro, entende-se que o fato gerador do imposto de renda não ocorreu, tendo em vista a ausência da importância em dinheiro obtido no momento do recebimento do bem.

Somente será possível verificar a ocorrência do fato gerador quando da venda do bem adquirido, verificando-se qual a alíquota a ser aplicada. Nesse caso, estaríamos diante da tributação sobre ganho de capital, utilizada em matéria de imposto de renda de pessoa física, quando da venda de bens.

Ademais, há um outro fator determinante, que é o princípio da legalidade, pois o dispositivo em voga não possui fundamento de validade por ter sido instituído mediante Decreto e não por Lei. E é justamente a inexistência de previsão legal do artigo 55, IV do RIR/99 que traz 
consequências essenciais para o tema em discussão, ou seja, Planos atrelados a ações, como será abordado a seguir.

\subsection{Fato Gerador do Imposto de Renda - Pessoa Física (IRPF) nos Stock Options Plans}

Conforme explicitado reiteradas vezes acima, conclui-se que o fato gerador do imposto de renda da pessoa física é a disponibilidade econômica da renda ou proventos de qualquer natureza verificada pelo regime de caixa e que represente ao beneficiário efetivo acréscimo patrimonial.

Quando fala-se em Plano de Ações, deve-se então observar se a pessoa física do beneficiário estará sujeita à tributação, e em caso positivo, qual a alíquota aplicável incidente sobre o acréscimo patrimonial obtido.

Cada Plano de Ações possui suas peculiaridade, o que faz com que as conclusões acerca da tributação varie caso a caso. Porém, é comum a todos os tipos de Planos de Ações a aplicação dos artigos $116^{29}$ e $117^{30}$ do Código Tributário Nacional.

Isto porque, entre a outorga e a maturação (Grant - Vesting) do Plano, não se pode falar em fato gerador do imposto de renda, uma vez que não há disponibilidade econômica por parte da pessoa física beneficiária. Somente quando as ações passarem a de fato a integrar o patrimônio do beneficiário é que se faz necessário o atingimento das metas e condições prefixadas. Sendo assim, por força do que dispõe o artigo 117, I do Código Tributário Nacional, o fato gerador do imposto de renda da pessoa física só poderá ocorrer quando restarem cumpridas as mencionadas condições.

\footnotetext{
${ }^{29}$ Art. 116. Salvo disposição de lei em contrário, considera-se ocorrido o fato gerador e existentes os seus efeitos:

(...)

II - tratando-se de situação jurídica, desde o momento em que esteja definitivamente constituída, nos termos de direito aplicável.

${ }^{30}$ Art. 117. Para os efeitos do inciso II do artigo anterior e salvo disposição de lei em contrário, os atos ou negócios jurídicos condicionais reputam-se perfeitos e acabados:

I - sendo suspensiva a condição, desde o momento de seu implemento;
} 
Após o período de maturação é que a análise de cada Plano se torna imprescindível para se verificar a ocorrência do fato gerando do IR, tendo em vista suas peculiaridades. O objeto do presente estudo são os Planos de Opções de Compra de Ações (Stock Options - SOPs), razão pela qual será o nosso Plano em análise para fins de tributação do IRPF.

Stock Options Plans consiste em Planos de Ações em que há a outorga do direito à pessoa física (empregado/beneficiário) de adquirir ações da companhia em determinado período no futuro, com preço também prefixado, desde que atingidas determinadas condições previamente acordadas. Esse tipo de Plano de Ações pressupões na maioria dos casos o desembolso/investimento por parte do empregado caso de fato exerça o direito a ele oferecido.

A questão que muitas vezes gera discussão é se essa possibilidade de adquirir ações por um preço menor do que aquele à data da aquisição pode configurar como fato gerador do imposto de renda da pessoa física. Porém, como vimos, o fato gerador do imposto de renda da pessoa física é a aquisição econômica da renda, o que somente ocorrerá em momento posterior, quando da venda das ações adquiridas, ocasião em que se aplicará a alíquota do ganho de capital. Por esta razão, a resposta para a indagação inicial tem caráter negativo.

Há quem sustente que conforme previsto na Lei $n^{0} 12.973 / 14$, os Planos de Ações impõe custos ou despesas à empresa e que valor para fins de dedutibilidade deve ser considerado também para fins de tributação pelo imposto de renda da pessoa física.

Todavia, esse entendimento não merece prosperar pelas seguintes razões:

“(i) o valor a ser considerado redutível pela empresa é uma mensurarão (e à época da concessão do Plano) daquilo que a empresa entende (isoladamente e sem a participação do beneficiário) poder servir de caráter contraprestacional por serviços a serem eventualmente prestados no futuro pelo beneficiário;

(ii) este valor, mensurado à época da concessão do Plano, não interfere na vida do beneficiário, pois para que o beneficiário possa eventualmente exercer o direito de adquirir as ações terá de desembolsar um valor prefixado para esta finalidade; 
(iii) se a pessoa física desembolsa para comprara ações, à evidência, não concorre para a ocorrência do fato gerador do imposto de renda, que, ao contrário, se dá não em caso de desembolso, mas de recebimento de receita; e

(iv) o eventual acréscimo patrimonial que tenha a ser identificado pelo exercício de compra das ações pela pessoa física se dá em momento deslocado daquele em que a empresa irá registrar o custo ou despesa incorridos pela concessão/outorga do Plano. A empresa deduz no momento em que a pessoa física exerce o direito de comprar as ações; a pessoa física encontra-se diante do fato gerado (acréscimo patrimonial decorrente da aquisição da disponibilidade econômica de renda) quando se desfaz das ações e obtém ganho, ao aplicar a tributação do ganho de capital."31

Diante de todo o exposto, conclui-se que não há fato gerador do imposto de renda da pessoa física na etapa do Plano do exercício do direito de adquirir ações. Deste modo, o imposto de renda somente poderá ser tributado quando da venda das ações e se houver efetivo ganho de capital ${ }^{32}$, que é representado pela diferença positiva entre o valor da venda das ações e o valor de sua aquisição ou investimento do empregado. Lembrando ainda, que a alíquota aplicável é aquela à época da venda das ações.

\footnotetext{
${ }^{31}$ LIBERTUCI, Elisabeth Lewandowski; VITO, Mariana Neves; SOUZA, Luciana Simões. Stock Options e Demais Planos de Ações. Quesões Tributárias Polêmicas e a Lei 12.973/2014. Revista dos Tribunais, São Paulo, 2015.

${ }^{32}$ Vale ressaltar que por configurar um negócio mercantil, há risco assumido por parte do empregado, podendo este obter lucro (que será tributado na forma de ganho de capital), ou prejuízo, que não será tributado para fins do IRPF, pois não ocorrerá acréscimo patrimonial.
} 


\section{CONCLUSÃO}

Como vimos, os Planos de Ações atualmente implementados, e mais precisamente os Stock Options Plans, possuem muitas peculiaridades, causando grandes vulnerabilidades sob o aspecto de incidências previdenciárias e fiscais.

A grande discussão que inicia a matéria concernente aos Planos atrelados a ações é o seu suposto caráter remuneratório. Como vimos, para que de fato a natureza mercantil das transações sejam afastadas, dando espaço para a configuração de remuneração, há de se provar a existência de habitualidade, reciprocidade e inexistência de risco.

Em outras palavras, para que de fato o fisco possa concluir pela incidência das contribuições previdenciárias, além de uma análise minuciosa de cada caso - quando são analisados os Planos definidos em Assembléia Geral - bem como seus termos e condições, deve restar comprovado que de fato não houve desembolso por parte do empregado, e que este não incorre me nenhum risco.

Porém, dando um caráter um tanto pessoal no presente estudo, acredito que diante de tudo que foi exposto, fica evidente que os Stock Options Plans pressupõem a existência de risco do negócio, uma vez que nem sempre as ações adquiridas terão o mesmo valor no momento de sua alienação. Da mesma forma que o beneficiário pode obter ganho, também pode ter que arcar com perda, advinda da oscilação do valor das ações no mercado mobiliário.

Da mesma forma, no tocante ao Imposto de Renda da Pessoa Física, me filio ao entendimento de que não há fato gerador do imposto de renda da pessoa física quando do exercício do direito de adquirir ações. O referido Imposto de Renda somente poderá ser verificado quando da efetiva disponibilidade econômica pela venda das ações adquiridas, acarretando 
acréscimo patrimonial. Em havendo ganho de capital, este será tributado de acordo com a alíquota aplicável.

Pode-se concluir então, que em regra não incide contribuições previdenciárias nos Stock Options Plans, desde que verificados todos os seus requisitos de validade. Bem como no caso do imposto de renda da pessoa física, deve restar comprovado que a operação proporcionou auferição de "renda acréscimo" (lucro/ganho de capital) por parte do beneficiário. Por isso, a minuciosa avaliação caso a caso é imprescindível para determinar acerca de sua tributação. 


\section{BIBLIOGRAFIA}

AMARO, Luciano. Direito tributário brasileiro. 20. ed. São Paulo: Saraiva, 2014.

BARROS, Alice Monteiro. Curso de direito do trabalho. São Paulo: Ed. LTR, 2010. p. 783.

BECKER, Alfredo Augusto. Teoria geral do direito tributário. 3. ed. 2. tir. São Paulo: Lejus, 2002.

BRASIL, Legislação. Disponível em: [www.planalto.gov.br]. Acesso em 01 de jun 2015.

CALVO, Adriana. A natureza jurídica dos planos de opções de compra de ações no direito do trabalho - ('employee stock option plans'). Disponível em: <http://www.calvo.pro.br/>. Acesso em 29 de out 2015.

CARRAZZA, Roque Antonio. Curso de direito constitucional tributário. 29. ed. São Paulo: Malheiros, 2012.

CARVALHOSA, Modesto. Comentários à Lei de Sociedades Anônimas. 6 ed. São Paulo: Saraiva, 2014, vol 1.

. Comentários à lei de sociedades anônimas. V.2.

4.ed. rev.e atual. São Paulo: Saraiva, 2008.

COELHO, Fábio Ulhoa. Curso de Direito Comercial V.2: Direito de Empresa.17.ed. São Paulo: Saraiva, 2013.

FARO, Maurício Pereira; ALMEIDA, José Muniz. Tratamento dos Planos de Stock Options após o CPC 10. In: ROCHA, Sergio André. Direito Tributário, Societário e a reforma da Lei das S/A - Alterações das Leis n ${ }^{0}$ 11.638/07 e 11.941/09. São Paulo: Quartier Latin, 2010. vol 2.

GIFIS, Steven H. Barron's dictionary of legal terms. 4.ed. Nova York: Barron’s, 2008. 
GRECO, Marco Aurélio. Contribuições: uma figura sui generis. São Paulo: Dialética, 2000.

HIGUCHI, Hiromi. Imposto de renda das empresas. 40. ed. São Paulo: IR Publicações, 2015.

LIBERTUCI, Elisabeth Lewandowski; VITO, Mariana Neves; SOUZA, Luciana Simões. Stock Options e Demais Planos de Ações. Quesões Tributárias Polêmicas e a Lei 12.973/2014. Revista dos Tribunais, São Paulo, 2015. p.131

MACHADO, Hugo de Brito. Curso de direito tributário. 34. ed. São Paulo: Malheiros, 2013.

MARTINEZ, Wladimir Novaes. Curso de direito previdenciário. Noções de direito previdenciário. 6.ed. São Pualo: Ed. LTr, 2008. t. I.

MARTINS, Sergio Pinto. Direito da seguridade social. 32. ed. São Paulo: Atlas, 2012. p. 124.

- Natureza do Stock Option no Direito do Trabalho. Suplemento OT - Legislação, Jurisprudência e Doutrina, ano XXIV, n. 11, p. 3, São Paulo: Thomson IOB, now 2005.

SOUZA, Rubens Gomes. Pareceres I - Imposto de Renda. Edição Póstuma. São Paulo: Resenha Tributária, 1975. p. 70. 